\title{
Emerging Role of Phospholipase-Derived Cleavage Products in Regulating Eosinophil Activity: Focus on Lysophospholipids, Polyunsaturated Fatty Acids and Eicosanoids
}

\author{
Eva Knuplez (D), Eva Maria Sturm and Gunther Marsche *(D) \\ Otto Loewi Research Center, Division of Pharmacology, Medical University of Graz, 8010 Graz, Austria; \\ eva.knuplez@medunigraz.at (E.K.); eva.sturm@medunigraz.at (E.M.S.) \\ * Correspondence: gunther.marsche@medunigraz.at
}

check for updates

Citation: Knuplez, E.; Sturm, E.M.; Marsche, G. Emerging Role of Phospholipase-Derived Cleavage Products in Regulating Eosinophil Activity: Focus on

Lysophospholipids, Polyunsaturated Fatty Acids and Eicosanoids. Int. J. Mol. Sci. 2021, 22, 4356. https:// doi.org/10.3390/ijms22094356

Academic Editor: Isabelle C. Arnold

Received: 25 March 2021

Accepted: 19 April 2021

Published: 21 April 2021

Publisher's Note: MDPI stays neutral with regard to jurisdictional claims in published maps and institutional affiliations.

Copyright: (c) 2021 by the authors. Licensee MDPI, Basel, Switzerland. This article is an open access article distributed under the terms and conditions of the Creative Commons Attribution (CC BY) license (https:// creativecommons.org/licenses/by/ $4.0 /)$.

\begin{abstract}
Eosinophils are important effector cells involved in allergic inflammation. When stimulated, eosinophils release a variety of mediators initiating, propagating, and maintaining local inflammation. Both, the activity and concentration of secreted and cytosolic phospholipases (PLAs) are increased in allergic inflammation, promoting the cleavage of phospholipids and thus the production of reactive lipid mediators. Eosinophils express high levels of secreted phospholipase A2 compared to other leukocytes, indicating their direct involvement in the production of lipid mediators during allergic inflammation. On the other side, eosinophils have also been recognized as crucial mediators with regulatory and homeostatic roles in local immunity and repair. Thus, targeting the complex network of lipid mediators offer a unique opportunity to target the over-activation and 'pro-inflammatory' phenotype of eosinophils without compromising the survival and functions of tissue-resident and homeostatic eosinophils. Here we provide a comprehensive overview of the critical role of phospholipase-derived lipid mediators in modulating eosinophil activity in health and disease. We focus on lysophospholipids, polyunsaturated fatty acids, and eicosanoids with exciting new perspectives for future drug development.
\end{abstract}

Keywords: eosinophils; phospholipase; lipid mediators; arachidonic acid; eicosanoids; prostaglandins; leukotrienes; lysophospholipids; endocannabinoids

\section{Introduction}

Eosinophils are multifunctional leukocytes involved in the host defense against helminth infections, tissue homeostasis, and tissue repair [1-3]. Eosinophils are capable of releasing a variety of mediators upon activation that both promote and maintain local inflammation and contribute to the pathogenesis of allergic disease [3,4]. Eosinophils contain secondary granules consisting of cytotoxic major basic protein, eosinophil-derived neurotoxin, eosinophil peroxidase, eosinophil cationic protein, and transforming growth factor beta (TGF- $\beta$ ), all of which contribute to airway remodeling [5]. The effector functions of eosinophils promote airway epithelial damage and hyperreactivity, and thereby contribute to all major hallmarks of asthma pathophysiology [6]. Therefore, eosinophil tissue recruitment and activation have long been considered as potential targets for the discovery and development of anti-allergy drugs.

Recent breakthroughs in eosinophil targeting have been made in the field of biologics and have been discussed in detail elsewhere [7]. The application of monoclonal antibodies, such as benralizumab (targeting the interleukin (IL)-5 receptor) or lirentelimab (anti-Siglec8 antibody), results in almost complete eosinophil elimination from blood and tissues, improving the patient's clinical score and symptoms $[8,9]$.

Recently, however, it has been recognized that eosinophils are crucial for local immunity and repair (LIAR hypothesis), by promoting immunoregulation and tissue homeostasis [1,2,10]. An important function of eosinophils is their antitumor effect in colorectal 
cancer [10-12]. For example, using a high-throughput evaluation of human primary tumors, Grisaru-Tal et al. identified differential infiltration of eosinophils in anatomically distinct tumors, with high eosinophil counts in mucosal barrier organs such as the colon or esophagus [13]. Eosinophils additionally show hepatoprotective activity [14] and cardiac protective function after myocardial infarction [15]. Of particular interest, a robust inverse correlation between eosinophil numbers and severity of novel coronavirus disease of 2019 (COVID-19) infection was observed [16-20]. Furthermore pre-existing eosinophilia in asthmatics was proven to be protective against COVID-19-associated hospital admission, while development of eosinophilia during hospitalization was associated with decreased mortality [21]. Taken together, these new findings call into question the long-term effects of eosinophil-depleting antibodies [22] and point to an unmet need of targeting eosinophil overactivation without completely depleting this multifunctional immune cell type.

It has long been known that both the concentration and activity of secreted and cytosolic phospholipases are increased in allergy and allergic inflammation, leading to increased phospholipid cleavage and lipid mediator production [23,24]. In fact, eosinophils have been discovered to express high levels of secreted phospholipase $\mathrm{A}_{2}$ in comparison to other leukocytes, indicating their involvement and contribution to lipid mediator production during allergic inflammation [25]. Recently, dysregulated fatty acid metabolism was identified in nasal polyp-derived eosinophils from patients with chronic rhinosinusitis [26], asthma [27], and other eosinophilic allergic diseases [28]. Therefore, targeting the complex network of lipid mediators has the potential to suppress eosinophil over-activation in allergy.

In this comprehensive review, we highlight the emerging role of phospholipases in regulating eosinophil activity, with a focus on reactive phospholipase-derived cleavage products, including lysophospholipids, polyunsaturated fatty acids, and eicosanoids.

\section{Phospholipases Play a Key Role in Allergies}

Phospholipases are enzymes that generate bioactive cleavage products, such as lysophospholipids and free fatty acids by cleaving membrane phospholipids. They can be broadly divided into two main groups depending on the site of phospholipid molecule cleavage [29]. Phospholipases A and B are acylhydrolases, hydrolyzing ester bonds at sn-1 and sn-2 position of the phospholipid molecule, while phospholipases $C$ and $D$ are phosphodiesterases [30]. Generally, phospholipases differ in their tissue expression patterns, cellular location, as well as substrate specificity [29]. Due to their ability to produce bioactive lipid mediators, they have long been considered as important enzymes involved in the pathogenesis of allergic inflammation [31].

\subsection{Phospholipase $A_{2}\left(P L A_{2}\right)$ and Eosinophils}

Phospholipases $\mathrm{A}_{2}$ are rate limiting enzymes cleaving phospholipids at the sn-2 position and thereby producing a free fatty acid and a lysophospholipid. The best described $\mathrm{PLA}_{2}$-derived free fatty acid is arachidonic acid-a precursor for the diverse family of eicosanoids [32]. The family of PLA $\mathrm{A}_{2}$ comprises secreted phospholipases $\mathrm{A}_{2}\left(\mathrm{sPLA}_{2}\right)$, cytosolic phospholipases $\mathrm{A}_{2}\left(\mathrm{cPLA}_{2}\right), \mathrm{Ca}^{2+}$-independent phospholipases $\mathrm{A}_{2}\left(\mathrm{iPLA}_{2}\right)$, platelet activating factor acetylhydrolases (PAF-AH), and lysosomal PLA (LPLA $_{2}$ [33]. Interestingly, endogenous $\mathrm{PLA}_{2}$ activity was shown to regulate human eosinophil degranulation, therefore contributing to their cytotoxic functions [34].

\subsubsection{Secreted Phospholipases $A_{2}$}

Levels of secreted phospholipases $\mathrm{A}_{2}\left(\mathrm{sPLA}_{2}\right)$ have been found to be increased in the lungs and bronchoalveolar lavage fluid (BALF) of asthmatics following allergen challenge [24,35]. Moreover, analysis of the plasma metabolome discovered increased activity of sPLA 2 in the lungs of guinea pigs in eosinophilic inflammation, while the levels of its substrate phosphatidylcholine were found to be decreased [36]. 
Recently, a specific subset of sPLA ${ }_{2}-\mathrm{SPLA}_{2}$ group $\mathrm{X}$ was identified to play a crucial role in allergic inflammation and airway responses to inhaled allergens [37-39]. Nolin et al. described that genetic deficiency of $\mathrm{SPLA}_{2}-\mathrm{X}$ results in a significant reduction in airway hyperresponsiveness as well as eosinophil trafficking into the airways [37]. Interestingly, endogenous expression of $\mathrm{sPLA}_{2}-\mathrm{X}$ has been described in eosinophils isolated from asthmatic patients. Endogenous $\mathrm{SPLA}_{2}-\mathrm{X}$ in eosinophils can translocate to granules and lipid bodies upon eosinophil activation and induce eicosanoid production through cytosolic $\mathrm{PLA}_{2}$ activation [40]. Similar mechanism of action and effects are observed, when exogenous sPLA ${ }_{2}-\mathrm{X}$ is added to eosinophils [41]. Importantly, targeting of $\mathrm{sPLA}_{2}-\mathrm{X}$ with specific small-molecule inhibitors such as RO061606 or ROC-0929 decreases eicosanoid release, allergen-induced airway inflammation, mucus hypersecretion, and hyperresponsiveness in preclinical studies (Table 1) [40,42]. Another subtype, sPLA2 group V-has recently been implicated in allergic inflammation $[43,44]$. It has been shown that macrophageassociated sPLA $\mathrm{A}_{2}-\mathrm{V}$ activates lung type 2 innate lymphoid cells (ILC2s) and leads to lung eosinophilia through the increase of IL-33 [45]. Even though eosinophils were not found to express $\mathrm{SPLA}_{2}-\mathrm{V}$ themselves, it was demonstrated that exogenously added human $\mathrm{SPLA}_{2}-$ $\mathrm{V}$ can activate eosinophils, inducing the liberation of arachidonic acid and eicosanoid production [46].

Table 1. Novel therapeutic options targeting lipid mediators with potential for targeting eosinophilic over-activation.

\begin{tabular}{|c|c|c|c|}
\hline Compound & Mode of Action & Published Effects & References \\
\hline $\begin{array}{l}\text { RO061606 } \\
\text { ROC-0929 }\end{array}$ & inhibitor of $\mathrm{sPLA}_{2}-\mathrm{X}$ & $\begin{array}{c}\text { Inhibition of eicosanoid formation. } \\
\text { Decrease in allergen-induced airway } \\
\text { inflammation, mucus hypersecretion and } \\
\text { hyperresponsiveness. }\end{array}$ & {$[40,42]$} \\
\hline $\begin{array}{l}\text { trifluoromethyl } \\
\text { ketone }\end{array}$ & inhibitor of $\mathrm{cPLA}_{2}$ & $\begin{array}{l}\text { Inhibition of antigen-induced airway } \\
\text { eosinophil accumulation and airway } \\
\text { hyperresponsiveness to methacholine. }\end{array}$ & [47] \\
\hline ZPL-521 & inhibitor of $\mathrm{CPLA}_{2}$ & $\begin{array}{l}\text { Clinical data: efficacious for treatment of } \\
\text { atopic dermatitis:improvement on the } \\
\text { eczema severity score, safe, well tolerated. }\end{array}$ & [48] \\
\hline GK452, GK504, GK484 & $\begin{array}{c}\text { inhibitors of } \mathrm{cPLA} \mathrm{A}_{2} \\
\text { with improved ADME properties }\end{array}$ & Decreased eicosanoid production. & {$[49,50]$} \\
\hline rhPAF-AH & hydrolysis of PAF to lysoPAF & $\begin{array}{l}\text { Preclinical model: significant reduction in } \\
\text { airway eosinophil infiltration, mucus } \\
\text { hypersecretion, and airway hyperreactivity } \\
\text { in response to methacholine challenge. } \\
\text { Clinical data: No improvement in } \\
\text { symptoms in mild asthma. }\end{array}$ & {$[51,52]$} \\
\hline rupatadine & $\begin{array}{l}\text { dual antagonist of } \mathrm{H} 1 \text { receptor } \\
\text { and PAF receptor }\end{array}$ & $\begin{array}{l}\text { In use for the treatment of urticaria and } \\
\text { allergic rhinitis in adults and children. } \\
\text { Reduces the levels of infiltrating } \\
\text { eosinophils in allergic rhinitis. }\end{array}$ & {$[53,54]$} \\
\hline miltefosine & $\begin{array}{l}\text { lipid raft modulator, } \\
\text { PLC inhibitor }\end{array}$ & $\begin{array}{l}\text { Inhibits activation, degranulation, and } \\
\text { migration of human eosinophils; decreases } \\
\text { immune cell infiltration and improves lung } \\
\text { function parameters in a model of allergic } \\
\text { lung inflammation. } \\
\text { Clinical data: efficacious and safe in an } \\
\text { antihistamine-resistant chronic } \\
\text { spontaneous urticaria. }\end{array}$ & {$[55,56]$} \\
\hline $\begin{array}{c}\text { resolvinE3 } \\
\text { (RvE3),18-deoxy-RvE3 }\end{array}$ & antagonism of BLT1 & $\begin{array}{l}\text { Decreased immune cell infiltration in a } \\
\text { model of allergic inflammation, } \\
\text { improvement in lung function parameters. } \\
\text { Decreased polymorphonuclear leukocytes } \\
\text { (PMNs) in the peritoneal exudates. }\end{array}$ & {$[57,58]$} \\
\hline
\end{tabular}


Table 1. Cont.

\begin{tabular}{|c|c|c|c|}
\hline Compound & Mode of Action & Published Effects & References \\
\hline protectin D1 & proposed action on GPR37 & $\begin{array}{l}\text { Decreased eosinophil recruitment to the } \\
\text { lungs, improvement in lung function } \\
\text { parameters and airway mucus secretion. } \\
\text { Accelerated resolution of } \\
\text { airway inflammation. }\end{array}$ & {$[59,60]$} \\
\hline stable $\mathrm{LXA}_{4}$ analogues & ALX/FPR2 receptor agonist & $\begin{array}{l}\text { Preclinical: Inhibition of airway } \\
\text { hyperresponsiveness and inflammation; } \\
\text { Clinical: well tolerated, topical- reduces the } \\
\text { severity of infantile eczema, inhaled- } \\
\text { improves lung function in mild asthmatics }\end{array}$ & [61-63] \\
\hline S-777469 & $\mathrm{CB}_{2}$ receptor agonist & $\begin{array}{l}\text { Preclinical: inhibition of skin inflammation } \\
\text { and eosinophil infiltration in mice by } \\
\text { blocking the activities of 2-AG. Phase } \\
\text { Ib/IIa clinical study for atopic dermatitis } \\
\text { ongoing (NCT00697710). }\end{array}$ & [64] \\
\hline
\end{tabular}

Inhibition of eosinophil migration induced

$$
\text { by } 2-A G \text { in vitro. }
$$

JZL184 MGL inhibitor Inhibition of airway hyperreactivity and airway inflammation in an LPS-induced model of airway inflammation.

\begin{tabular}{|c|c|c|c|}
\hline GWJ-23 & LysoPLD (autotaxin) inhibitor & $\begin{array}{l}\text { Reduced inflammation in a triple-allergen } \\
\text { mouse asthma model }\end{array}$ & [67] \\
\hline ki16425 & antagonist of LPA receptor 1 and 3 & $\begin{array}{c}\text { Prevents bradykinin induced asthmatic } \\
\text { bronchoconstriction and reduces associated } \\
\text { respiratory distress following } \\
\text { allergen exposure }\end{array}$ & {$[68]$} \\
\hline FPS-ZM1 & $\begin{array}{l}\text { RAGE receptor } \\
\text { antagonist }\end{array}$ & $\begin{array}{l}\text { Inhibits rIL-5/13-mediated airway mucus } \\
\text { metaplasia and allergic inflammation, } \\
\text { including eosinophil infiltration. }\end{array}$ & [69] \\
\hline zileuton & 5-LO inhibitor & $\begin{array}{l}\text { In use: prophylaxis and treatment of } \\
\text { chronic asthma }\end{array}$ & {$[70]$} \\
\hline $\begin{array}{l}\text { montelukast } \\
\text { zafirlukast }\end{array}$ & $\begin{array}{l}\text { Cys- } \mathrm{LT}_{1} \text { receptor } \\
\text { antagonist }\end{array}$ & $\begin{array}{l}\text { In use: prophylaxis and chronic treatment } \\
\text { of asthma, the prevention of } \\
\text { exercise-induced bronchospasm, and the } \\
\text { relief of symptoms of allergic rhinitis. }\end{array}$ & [71] \\
\hline $\begin{array}{l}\text { TAS-205 } \\
\text { HQL-79 }\end{array}$ & hPGDS inhibitor & $\begin{array}{l}\text { In combination with montelukast showed } \\
\text { additive inhibitory effects on eosinophil } \\
\text { infiltration and late phase nasal obstruction } \\
\text { in a model of allergic rhinitis. } \\
\text { Ameliorated airway inflammation in an } \\
\text { ovalbumin model of allergic } \\
\text { airway inflammation. }\end{array}$ & {$[72,73]$} \\
\hline fevipiprant & DP2 receptor antagonist & $\begin{array}{l}\text { Phase III clinical studies did not show a } \\
\text { statistically significant reduction in asthma } \\
\text { exacerbations after adjusting for multiple } \\
\text { testing; however, consistent and modest } \\
\text { reductions in exacerbations rates were } \\
\text { observed with the } 450 \mathrm{mg} \text { (higher) dose. }\end{array}$ & [74] \\
\hline ONO-0453 & DP1 receptor antagonist & $\begin{array}{l}\text { Shows improvement in all nasal and eye } \\
\text { symptoms in a Phase II clinical study in } \\
\text { seasonal allergic rhinitis patients. }\end{array}$ & {$[75]$} \\
\hline
\end{tabular}


Table 1. Cont.

\begin{tabular}{|c|c|c|c|}
\hline Compound & Mode of Action & Published Effects & References \\
\hline butaprost & EP2 receptor agonist & $\begin{array}{l}\text { Ameliorates airway inflammation and } \\
\text { allergen-induced accumulation of } \\
\text { eosinophils in the lungs of } \\
\text { ovalbumin-sensitized mice. } \\
\text { Limits airway hyperresponsiveness and } \\
\text { inflammation in a house dust mite } \\
\text { induced model. }\end{array}$ & {$[76,77]$} \\
\hline iloprost & stable analogue of $\mathrm{PGI}_{2}$ & $\begin{array}{l}\text { Inhibits eosinophil trafficking and } \\
\text { improves cardinal features of asthma in } \\
\text { preclinical models }\end{array}$ & {$[78,79]$} \\
\hline S-Y048 & $\begin{array}{c}\text { 5-oxo-ETE receptor } \\
\text { antagonist }\end{array}$ & $\begin{array}{l}\text { Inhibits eosinophil infiltration in the skin } \\
\text { following intradermal allergen challenge in } \\
\text { primates. }\end{array}$ & [80] \\
\hline
\end{tabular}

\subsubsection{Cytosolic Phospholipases $A_{2}$}

Cytosolic phospholipases $\mathrm{A}_{2}$ have long been recognized as vital for eicosanoid production, since inherited cPLA ${ }_{2}$ deficiency leads to widespread decreases in eicosanoid levels in humans [81]. Furthermore, increased expression of group IV cPLA2 has been identified in sputum cells from subjects with asthma and exercise-induced bronchoconstriction [82]. The involvement of cPLA 2 -IV in eosinophil over-activation have been demonstrated in preclinical models, and $\mathrm{CPLA}_{2}$ inhibition prevented both eosinophilic infiltration and subsequent airway hyperresponsiveness after antigen challenge [47]. Moreover, clinical data from patients suffering from hyper-eosinophilic syndrome suggests that increased and activated (phosphorylated and membrane-translocated) $\mathrm{CPLA}_{2}$-IV is involved in the augmented release of leukotriene $\mathrm{C} 4$ from isolated eosinophils [83].

Drug development of specific cPLA 2 inhibitors for treatment of asthma and allergic diseases has been underway for the past two decades, with many orally-bioavailable compounds entering human clinical trials [84-86] (Figure 1). For example, a topical solution of the $\mathrm{CPLA}_{2}$ inhibitor ZPL-521 has now completed a phase Ilb clinical trial for treatment of atopic dermatitis [48] (NCT02795832). However, a major drawback of previously developed small inhibitors targeting $\mathrm{cPLA}_{2}$ is their high lipophilicity, which leads to unfavorable absorption, distribution, metabolism, and excretion [85]. Lately, a novel class of highly potent $\mathrm{CPLA}_{2}$-IV oxo-ester inhibitors with a favorable lipophilic profile was developed and characterized by Kokotou et al. [49]. These compounds (GK452, GK504, GK484) potently inhibit prostaglandin D2 production, but remain to be tested on eosinophils $[49,50]$.

\subsubsection{Platelet Activating Factor Acetylhydrolase (PAF-AH)}

PAF-AH hydrolyses the acetyl ester at the sn-2 position of platelet activating factor (PAF), thus producing lyso-PAF (alkyl-lysophosphatidylcholine) [87]. A minor fraction of PAF is synthesized de novo, while the main fraction of PAF is formed by the enzyme lysophosphatidylcholine acetyl-transferase (LPCAT) [88]. Both, pro-inflammatory and pro-allergic actions of PAF have been extensively studied as described by Gill et al. in detail [89]. Eosinophils, in particular, were found to produce PAF in response to chemotactic stimuli [89]. PAF was found to potently induce eosinophil degranulation in a non-receptor mediated fashion [90]. It was previously demonstrated that asthmatics have reduced levels of PAF-AH and application of recombinant PAF-AH showed great therapeutic potential in animal models of asthma [51]. However, a clinical trial investigating the use of recombinant human PAF-AH in mild asthmatics showed no improvement in clinical symptoms [52]. 


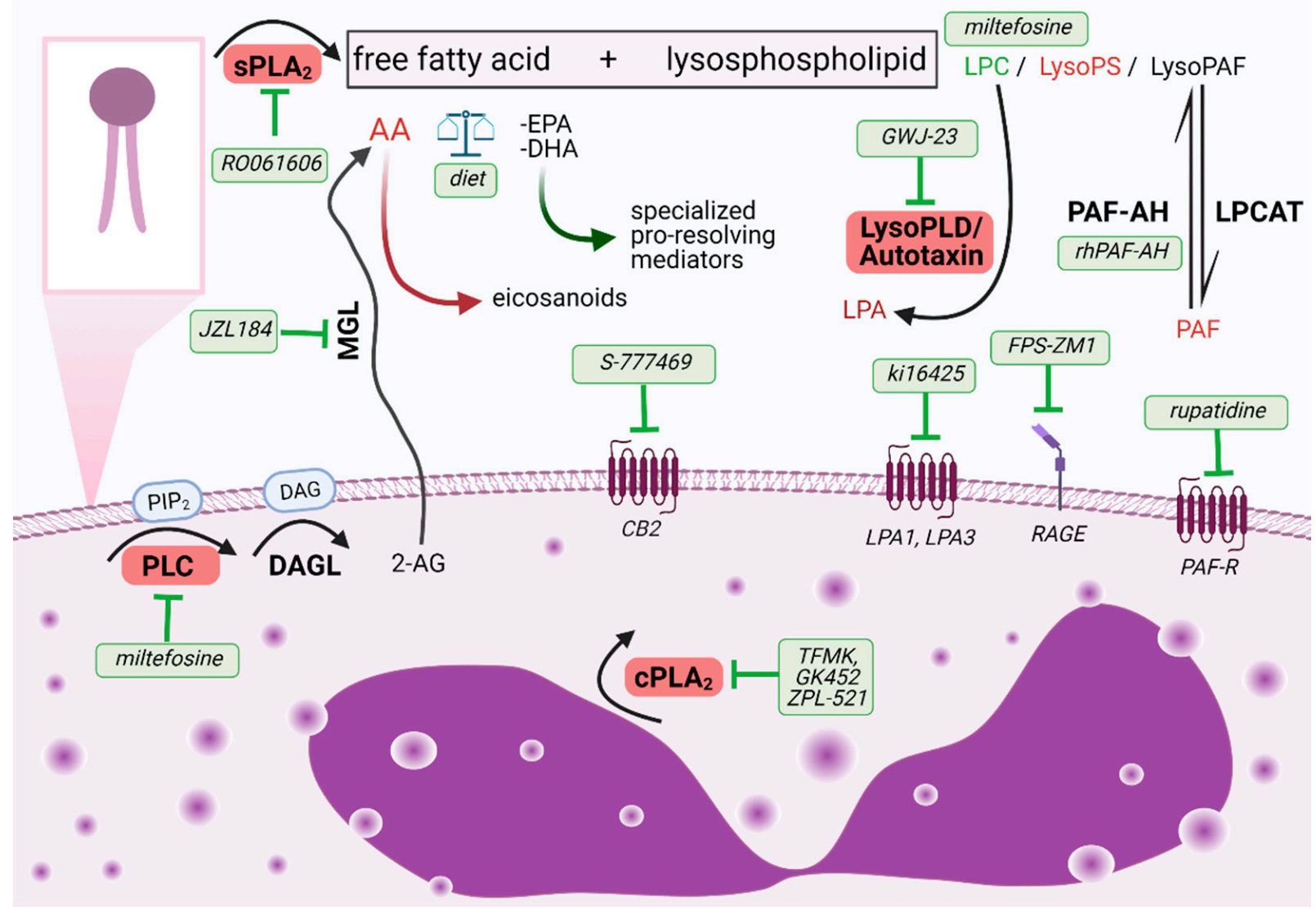

Figure 1. Overview of the phospholipid cleavage by phospholipases and major bioactive mediators produced during this process. Identified potential inhibitors of (i) enzyme activities or (ii) receptor antagonists targeting eosinophil over-activation are highlighted in green. Abbreviations: 2-AG, 2-arachidonoylglycerol; AA, arachidonic acid; CB2, cannabinoid receptor type 2, cPLA 2, cytosolic phospholipase A2; DAG, diacylglycerol; DAGL, diacylglycerol lipase; DHA, docosahexaenoic acid; EPA, eicosapentaenoic acid; LPA, lysophosphatidic acid; LPA1,3, lysophosphatidic acid receptors type 1 and 3; LPC, lysophosphatidylcholine; LPCAT, lysophosphatidylcholine acyltransferase; LysoPAF, lyso platelet-activating factor; LysoPLD, lysophophospholipase D; LysoPS, lysophosphatidylserine; MGL, monoacylglycerol lipase; PAF, platelet-activating factor; PAF-AH, platelet-activating factor acetylhydrolase; PAF-R, platelet-activating factor receptor; PIP2, phosphatidylinositol 4,5-bisphosphate; PLC, phospholipase C; RAGE, receptor for advanced glycation end products; sPLA 2 , secreted phospholipase A2.

PAF was shown to act on a specific $G$ protein-coupled receptor, inducing eosinophil activation, calcium flux, and prostanoid secretion [91,92]. Furthermore, PAF is a potent chemotactic and chemokinetic factor for eosinophils [93]. The effects of PAF and other phospholipid cleavage products on eosinophils have been summarized in Table 2. Currently, the orally bioavailable dual antagonist rupatadine (antagonist of the $\mathrm{H} 1$ histamine receptor and PAF-receptor) is indicated for use in urticaria and allergic rhinitis [94,95]. When compared with levocetirizine, rupatadine use resulted in less adverse effects as well as in significantly greater reductions in the total nasal symptoms score, serum immunoglobulin $\mathrm{E}$ (IgE) level as well as eosinophil counts in seasonal allergic rhinitis patients [53]. Moreover, studies conducted in pediatric allergic rhinitis patients demonstrated an acceptable safety profile and efficacy of rupatadine $[96,97]$. Rupatadine is recommended in current international guidelines as first-line therapy for the treatment of allergic rhinitis in children [98-100]. 
Table 2. Effects of phospholipid cleavage products on eosinophil functions.

\begin{tabular}{|c|c|c|}
\hline Bioactive Lipid Mediator & Mode of Action on Eosinophils & References \\
\hline 2-arachidonolyglycerol & $\begin{array}{l}\text { Induces chemotaxis } \\
\text { Induces calcium flux }\end{array}$ & $\begin{array}{l}{[68,101,102]} \\
{[103]}\end{array}$ \\
\hline 5-oxo-ETE & $\begin{array}{l}\text { Increases chemotaxis } \\
\text { Increases calcium flux, actin reorganization and ROS production } \\
\text { Increases infiltration in the skin following intradermal application } \\
\text { Upregulates eosinophil cationic protein in nasal polyps in vitro }\end{array}$ & $\begin{array}{l}{[104-106]} \\
{[104]} \\
{[107]} \\
{[108]}\end{array}$ \\
\hline Cysteinyl leukotrienes & $\begin{array}{l}\text { Induce chemotaxis and adhesion molecule upregulation } \\
\text { Induce eosinophil trans endothelial migration, superoxide } \\
\text { production and degranulation } \\
\text { Elicit secretion from within cell-free human eosinophil granules }\end{array}$ & $\begin{array}{l}{[109]} \\
{[110]} \\
{[111]}\end{array}$ \\
\hline Leukotriene B4 & Induces infiltration to the inflamed peritoneum & [112] \\
\hline Lipoxin A4 & $\begin{array}{l}\text { Inhibits eicosanoid-induced tissue migration and airway } \\
\text { hyperresponsiveness }\end{array}$ & [61] \\
\hline Lysophosphatidic Acid & $\begin{array}{l}\text { Increases CD11b upregulation, superoxide production, chemotaxis, } \\
\text { calcium flux and actin reorganization } \\
\text { Increases airway infiltration and superoxide production }\end{array}$ & $\begin{array}{l}{[113]} \\
{[114]}\end{array}$ \\
\hline Lysophosphatidylcholine & $\begin{array}{l}\text { Pro-inflammatory } \\
\text { Induces CD11b upregulation, adhesion and calcium flux } \\
\text { Increases infiltration in the airways and airway resistance } \\
\text { Anti-inflammatory } \\
\text { Inhibits CD11b upregulation, calcium flux, Akt and Erk } \\
\text { phosphorylation as well as in vitro and in vivo migration }\end{array}$ & $\begin{array}{l}{[115]} \\
{[116]} \\
{[101]}\end{array}$ \\
\hline Lysophosphatidylserine & $\begin{array}{l}\text { Induces degranulation } \\
\text { Induces eosinophil extracellular trap formation }\end{array}$ & $\begin{array}{l}{[102]} \\
{[117]}\end{array}$ \\
\hline Platelet Activating Factor & $\begin{array}{l}\text { Induces calcium flux } \\
\text { Increases chemokinesis and chemotaxis } \\
\text { Induces degranulation } \\
\text { Induces prostanoid secretion }\end{array}$ & $\begin{array}{l}{[92]} \\
{[93]} \\
{[90]} \\
{[91]}\end{array}$ \\
\hline Prostaglandin $\mathrm{D}_{2}$ & $\begin{array}{l}\text { DP2 } \\
\text { induces calcium flux, CD11b upregulation, migration and } \\
\text { degranulation } \\
\text { primes eosinophils for other chemoattractants } \\
\text { DP1 } \\
\text { prolongs survival } \\
\text { enhances DP2 signaling }\end{array}$ & $\begin{array}{l}{[118,119]} \\
{[120,121]} \\
{[118,122]} \\
{[122,123]}\end{array}$ \\
\hline Prostaglandin $\mathrm{E}_{2}$ & $\begin{array}{l}\text { Inhibits chemotaxis, CD11b upregulation, degranulation, calcium } \\
\text { flux, cytoskeletal rearrangement and reactive oxygen production } \\
\text { Prolongs their survival } \\
\text { Decreases sputum counts }\end{array}$ & $\begin{array}{c}{[76,124]} \\
{[125,126]} \\
{[127]}\end{array}$ \\
\hline Prostacyclin & $\begin{array}{l}\text { Inhibits migration and adhesion in vitro, reduces CD11b } \\
\text { upregulation and activation } \\
\text { Inhibits migration in vivo }\end{array}$ & $\begin{array}{l}{[128]} \\
{[79]}\end{array}$ \\
\hline Protectin D1 & $\begin{array}{l}\text { Inhibits chemotaxis as well as CD11b and L-selectin expression } \\
\text { Decreases airway infiltration and airway hyperresponsiveness }\end{array}$ & $\begin{array}{l}{[129]} \\
{[60]}\end{array}$ \\
\hline Resolvin E3 & $\begin{array}{l}\text { Reduces infiltrating airway eosinophils in an HDM-induced airway } \\
\text { inflammation model }\end{array}$ & [57] \\
\hline
\end{tabular}

\subsubsection{Phospholipase A2 Cleavage Products: Lysophospholipids}

The most common lysophospholipid produced by the action of phospholipases is lysophosphatidylcholine (LPC), which can reach plasma concentrations of up to $150 \mu \mathrm{M}$ already under physiological conditions [130]. LPC is an amphiphilic molecule possessing a long aliphatic chain and a polar head giving it surfactant-like properties. Under its 
critical micellar concentration, LPC favors the bending of the cell membrane to a positive curvature, thereby altering its properties [131]. If LPC is used in high concentrations or in the absence of carrier proteins (e.g., albumin), it induces cell membrane lysis and cell death [132]. The concentration of LPC increases under inflammatory conditions, with increased levels of LPC being observed in BALF of asthmatic patients [130,133]. Conversely, a novel metabolomics-based approach identified decreased levels of LPC species in patients suffering from asthma [134].

Studies investigating the effects of LPC on immune cells are contradictory [135]. Specifically, most older studies investigating the effects of LPCs on eosinophils found them to be proinflammatory-increasing the activation, adhesion, and migration of eosinophils $[115,116]$. However, in these studies, the authors used LPC in the absence of physiological carrier proteins, which explains the toxic effects induced by LPC on eosinophils [115]. Importantly, Marathe et al. identified that many commercially available LPC species contain PAF or PAF-like contaminants, which are responsible for the observed eosinophil-chemotactic potential [136]. Moreover, when LPC was investigated in animal models of allergy and asthma, prolonged LPC application was often used [116,137]. Since LPC is short-lived and rapidly metabolized in tissues by the action of lysophospholipases (generating pro-inflammatory lysophosphatidic acid or used as a precursor for phosphatidylcholine synthesis), it is therefore not possible to determine whether the observed pro-inflammatory effects are due to the action of LPC or its metabolites [138,139].

In fact, Kwatia et al. reported that a combined action of both secretory phospholipases and eosinophil-derived lysophospholipases is needed to induce a loss in surfactant activity as observed in asthma [140]. Moreover, the Charcot Leyden-Crystal (CLC) or galectin-10, which is one of the most abundant proteins in human eosinophils, has been reported to cleave palmitate from LPC 16:0 [141,142]. Interestingly, levels of CLC in sputum serve as robust biomarkers of eosinophilic inflammation and were recently reported to act as a type 2 adjuvant-stimulating adaptive and innate immunity $[143,144]$. When anti-CLC antibodies were applied to patient-derived mucus, they were capable of dissolving patient-derived CLCs. Furthermore, anti-CLC antibodies reversed goblet-cell metaplasia, IgE synthesis as well as bronchial hyperreactivity in a humanized mouse model of asthma [144]. Overall, these studies suggest that LPC itself is not responsible for the observed proinflammatory effects on eosinophils.

Saturated LPC species added to human eosinophils in the presence of the physiological carrier, serum albumin, strongly suppressed upregulation of CD11b and degranulation [101]. The anti-inflammatory effects of LPC appear to be mainly mediated by its action on cell membranes, where it disrupts lipid raft formation. This leads to suppression of receptor activation and downstream signaling effects, such as $\mathrm{Ca}^{2+}$ flux and kinase phosphorylation [101]. Short-term application of LPC in mice inhibited the infiltration of eosinophils into BALF [101]. Interestingly, LPC has been shown to act as a non-competitive product inhibitor of secreted PLA 2 , which may be another anti-inflammatory mechanism [145].

Consistent with the anti-inflammatory effects observed with LPC [101], the stable LPC analogue miltefosine showed very similar actions. Miltefosine is an orally bioavailable alkylphosphocholine drug approved for the treatment of leishmaniasis [55]. Similarly to LPC, miltefosine inhibited human eosinophil responses in vitro [55]. Moreover, in an ovalbumin model of allergic inflammation, miltefosine suppressed eosinophil infiltration into BAL fluid, ameliorated allergic inflammation in vivo and led to an improvement in lung function parameters [55]. Therefore, highlighting the potential of miltefosine as a novel treatment option dampening the over-activation of eosinophils.

Recently, another lysophospholipid has been investigated in the context of eosinophil activation. Hwang et al. demonstrated that lyosphosphatidylserine is capable of inducing eosinophil degranulation via its action on $\mathrm{P}_{2} \mathrm{Y}_{10}$ receptor [102]. A subsequent study demonstrated the ability of lysophosphatidylserine to induce eosinophil extracellular trap formation [117]. Because $\mathrm{P}^{2} \mathrm{Y}_{10}$ is highly expressed during late stage eosinophil 
differentiation and in eosinophils isolated from severe asthmatics, it offers the possibility of targeting eosinophil degranulation without affecting their survival [102,117].

\subsubsection{Phospholipase $A_{2}$ Cleavage Products: Free Fatty Acids}

The most recognized polyunsaturated fatty acid (PUFA) produced by the action of phospholipases is $\omega-6$ acid arachidonic acid (AA, 20:4) (Figure 2). Arachidonic acid can be metabolized by the action of cyclooxygenases (COX), lipoxygenases (LOX) and cytochrome P450 monoxygenases (CYP), leading to multiple bioactive mediator formation. COX enzymes produce prostaglandins and thromboxanes, LOX enzymes are responsible for the formation of leukotrienes and lipoxins while the CYP pathway generates hydroxyeicosatetraenoic acids (HETEs) and epoxy-eicosatrienoic acids (EETs) [146]. The products of AA metabolism and their targeting are described in detail in Section 3.

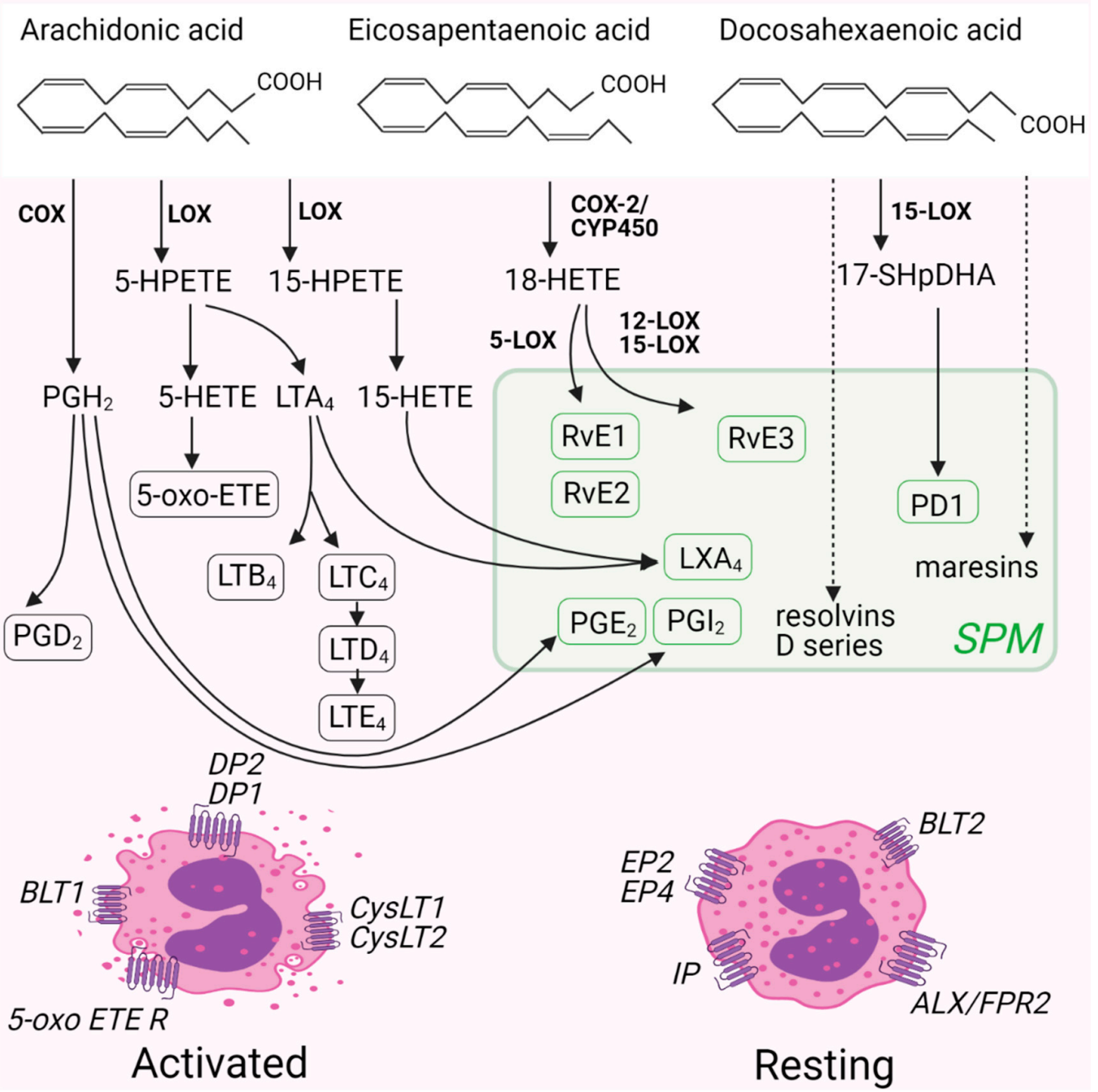

Figure 2. A schematic representation of PUVA metabolism into bioactive lipid mediators. PUVA are converted into bioactive lipid mediators capable of potentiating or inhibiting eosinophil activation via their specific $G$ protein-coupled receptors. Abbreviations: 5-oxo-ETE, 5-oxo-eicosatetraenoic acid; 5-oxo-ETE R, 5-oxo-eicosatetraenoic acid receptor; ALX/FPR2, lipoxin A4 receptor/formyl peptide receptor 2; BLT 1 or 2, leukotriene B4 receptor 1 or 2; COX, cyclooxygenase; CYP450, cytochrome P450; CysLT1 or 2, cysteinyl leukotriene receptor 1 or 2; DP1 or 2, prostaglandin D2 receptor 1 or 2; EP2 or 4; prostaglandin E2 receptor 2 or 4; HETE, hydroxyeicosatetraenoic acid, HPETE, hydroperoxyeicosatetraenoic acid; HpDHA, hydroperoxydocosahexaenoic acid; IP, prostacyclin receptor; LOX, lipoxygenase; LTA4, leukotriene A4; LTB4, leukotriene B4; LTC4, leukotriene C4; LTD4, leukotriene D4; LTE4, leukotriene E4; LXA4, lipoxin A4; PD1, protectin D1; PGD2, prostaglandin D2; PGE2, prostaglandin E2; PGH2, prostaglandin H2; PGI2, prostacyclin; RvE1, resolvin E1; RvE2, resolvin E2; RvE3, resolvin E3; SPM, specialized pro-resolving mediators. 
Other important PUFAs involved in inflammation and allergy are the $\omega-3$ acids eicosapentaenoic acid (EPA, 20:5) and docosahexaenoic acid (DHA, 22:6) (Figure 2). The supplementation of these $\omega-3$ acids with diet was previously associated with favorable outcomes in a variety of disease models [147-151]. Both, EPA and DHA supplementation was discovered to increase membrane fluidity and lipid raft clustering leading to decreased cell activation [152]. In addition, EPA and DHA were found to compete with AA as a substrate for LOX, COX, and CYP enzymes. This reduces the formation of AA metabolites and replaces them with a series of specialized pro-resolving mediators (SPMs) [28,153].

\section{Eicosanoids and Eosinophils}

Eicosanoids are a diverse group of short-lived bioactive mediators mainly metabolized from arachidonic acid, which control a wide range of physiological processes such as vasoconstriction and vasodilatation, gastric motility, and bronchoconstriction. Cells of the innate immune system such as neutrophils, macrophages, mast cells, and eosinophils are capable of producing large amounts of eicosanoids, which may potentiate or attenuate local inflammatory processes. Moreover, eicosanoids were reported to play a vital role in a variety of diseases ranging from allergy to autoimmunity and cancer. Eicosanoids predominantly bind to and activate G protein-coupled receptors (GPCRs) and therefore represent a readily targetable group of lipid mediators [154-156].

\subsection{Specialized Pro-Resolving Mediators: Resolvins, Protectins, and Lipoxins}

SPMs consist of E-series resolvins, D-series resolvins, protectins, maresins, as well as AA-derived lipoxins. This group of anti-inflammatory mediators inhibits polymorphonuclear leukocyte infiltration and promotes resolution of inflammation via macrophage clearance [157-159].

Eosinophils are a major source of resolvin E3 produced via the 12/15-LOX pathway, whereas neutrophils produce mainly resolvin E1 and resolvin E2 via the 5-LOX pathway [160]. Eosinophil-derived resolvin E3 was specifically found to inhibit the chemotaxis of polymorphonuclear cells [160]. Recently, Sato et al. described that resolvin E3 is capable of promoting the resolution of house dust mite-induced airway inflammation by regulating the expression of the leukotriene $\mathrm{B} 4$ receptor BLT $_{1}$ and inhibiting IL-17 and IL-23 cytokine release. This results in decreased immune cell infiltration into the airways and improved lung function parameters [57]. Following this discovery, novel highly potent (in fg dose range) deoxy-resolvin E3 derivates were synthesized and characterized [58]. Interestingly, eosinophils isolated from healthy individuals were discovered to generate high levels of protectin D1 through the action of 15-LOX. Protectin D1 has been similarly described to inhibit eosinophil chemotaxis and adhesion molecule expression, and to reduce airway hyperreactivity and inflammation in a preclinical model of allergic airway inflammation $[62,144,159]$. Interestingly, a lipidomics-based approach identified dysregulated PUFA metabolism in eosinophils in severe asthma [62,144,159]. In particular, 15-LOX-derived pro-resolving mediators such as protectin D1 and lipoxin A4 $\left(\mathrm{LXA}_{4}\right)$ were found to be decreased in severe asthma and associated with aspirin sensitivity in aspirin-exacerbated respiratory disease $[28,161-163]$. Finally, the levels of the $\mathrm{LXA}_{4}$ receptor are decreased in severe asthma [164]. Previously, multiple anti-inflammatory and anti-allergic properties in preclinical models have been attributed to a stable analogue of $\mathrm{LXA}_{4}$ [61].

Since then, clinical studies with $\mathrm{LXA}_{4}$ analogs have demonstrated safety and clinical efficacy as a topical solution for infant eczema (15(R/S)-methyl-lipoxin A(4)) [63] and for inhalation in asthmatic children with acute episode $(5(\mathrm{~S}), 6(\mathrm{R})$-lipoxin A4 methyl ester and BML-111) [62].

\subsection{Leukotrienes}

Leukotrienes are produced via enzymatic lipid peroxidation from arachidonic acid by the action of lipoxygenases (LOX). First, diverse LOX (5-LO, 12-LO and 15-LO) species convert arachidonic acid into hydroperoxyeicosatetraenoic acids (HpETEs) and HETEs. 
5-LO next converts the intermediate HpETE into a transient epoxide intermediate leukotriene $\mathrm{A}_{4}\left(\mathrm{LTA}_{4}\right)$. Finally, $\mathrm{LTA}_{4}$ can be further metabolized via three different pathways into cysteinyl leukotrienes $\left(\mathrm{LTC}_{4}, \mathrm{LTD}_{4}, \mathrm{LTE}_{4}\right), \mathrm{LTB}_{4}$ and into anti-inflammatory lipoxins (LXA and $\left.\mathrm{LXB}_{4}\right)[155,165]$.

Cysteinyl leukotrienes have been reported to bind to 5 different receptors with varying affinities-cysteinyl leukotriene receptors 1 and 2 (CysLT $1, C_{1}$ CLT $\left._{2}\right)$, as well as GPR99, GPR17 and P2Y 12 [165-167]. Eosinophils have been described to express CysLT 1, CysLT $_{2}$, GPR99 and P2Y 12 [168,169]. However, even though GPR17 expression has not been confirmed on eosinophils yet, a recent report describes higher GPR17 expression in nasal polyp tissue in eosinophilic versus non-eosinophilic chronic rhinosinusitis, suggesting its involvement in eosinophil infiltration [170]. It has long been recognized that eosinophils are a major source of cysteinyl leukotrienes [167,169]. Binding of cysteinyl leukotrienes to CysLT $_{1}$ on eosinophils was found to increase their transendothelial migration, superoxide generation, and degranulation $[109,110]$. Additionally, cysteinyl leukotrienes are capable of inducing secretion from cell-free eosinophilic granules by acting on the CysLT receptors expressed by the granules themselves [111].

$\mathrm{LTB}_{4}$ is produced from $\mathrm{LTA}_{4}$ by the action of $\mathrm{LTA}_{4}$ hydrolase [171]. In contrast to cysteinyl leukotrienes, only two different receptors have been identified for $\mathrm{LTB}_{4}$ - the so called $\mathrm{BLT}_{1}$ and $\mathrm{BLT}_{2}[172,173]$. Binding of $\mathrm{LTB}_{4}$ to its receptors has previously been demonstrated to result in potent chemotaxis of neutrophils and eosinophils [112,174]. Interestingly, a recent report by Pal et al. clearly describes that, even though $\mathrm{LTB}_{4}$ production has traditionally been attributed to neutrophils and alveolar macrophages, eosinophils are actually a major source of $\mathrm{LTB}_{4}$. The authors demonstrate that human eosinophils isolated from patients with severe asthma express the enzyme $\mathrm{LTA}_{4}$ hydrolase and produce $\mathrm{LTB}_{4}$ in response to stimuli [175].

Cysteinyl leukotrienes and $\mathrm{LTB}_{4}$ have long been implicated in allergy and $\mathrm{T}_{\mathrm{H}} 2$ type inflammation. Their role as potential therapeutic targets in allergic diseases has recently been comprehensively reviewed by Watanabe and colleagues [176]. In brief, the 5-LO inhibitor zileuton is currently registered for treatment of chronic asthma for patients of 12 years and older and additionally shows beneficial clinical improvement in upper airway inflammatory conditions and atopic dermatitis [70]. By decreasing the production of leukotrienes $\mathrm{B}_{4}, \mathrm{C}_{4}, \mathrm{D}_{4}$, and $\mathrm{E}_{4}$, zileuton reduces inflammation, edema, mucus secretion, and bronchoconstriction in the airways [70]. Further, montelukast, a specific antagonist of the $\mathrm{CysLT}_{1}$ receptor is routinely used for treatment of chronic asthma, prevention of exercise-induced bronchospasm, and the relief of allergic rhinitis symptoms [71,177]. Zafirlukast is another $\mathrm{CysLT}_{1}$ antagonist approved for the treatment of asthma in children 5 years of age and older, as well as off-label for allergic rhinitis and prophylaxis of exerciseinduced bronchospasm. Both CysLT $_{1}$ antagonists are administered orally and are preferred by children over inhaled corticosteroids [71]. Recently, montelukast additionally exhibited potential to reduce airway inflammation and hyperresponsiveness in a viral-triggered asthma exacerbation model [178].

While targeting the cysteinyl pathway resulted in successful clinical trials and drug development, the opposite can be said for targeting the $\mathrm{LTB}_{4} / \mathrm{BLT}_{1} / \mathrm{BLT}_{2}$ axis. While some earlier reports showed beneficial properties of $\mathrm{LTB}_{4}$ antagonist in vitro and in preclinical models, the results could not be reproduced in a clinical patient setting [179-181]. This contradicting data might be explained by recent findings demonstrating anti-inflammatory actions of the $\mathrm{BLT}_{2}$ receptor, opposing the pro-inflammatory actions of the $\mathrm{BLT}_{1}$ receptor [182-185].

Eosinophils have been found to express high levels of 15-LOX and are capable of metabolizing 15-HPETE into 14,15-leukotrienes [186,187]. Since eosinophils were discovered to be a major source of these mediators, they were later renamed into eoxins $[186,187]$. Treatment of eosinophils with arachidonic acid leads to the formation of eoxin (EX) $\mathrm{C}_{4}$, which can be further metabolized into $\mathrm{EXD}_{4}$ and $\mathrm{EXE}_{4}$. Moreover, mast cells, human nasal polyps, and airway epithelial cells were also reported to release eoxins, which act 
by increasing vascular permeability and enhancing edema formation [186-188]. Both the levels of 15-LOX and $\mathrm{EXC}_{4}$ have been reported to be increased in asthma [189-192]. However, a separate study by Ono et al. found no correlation between eosinophil counts and $\mathrm{EXC}_{4}$ concentration in bronchoalveolar lavage fluid of patients with inflammatory lung diseases [193]. So far, a specific eoxin receptor has not been identified [187].

\subsection{Prostaglandins}

Prostaglandins are bioactive mediators formed from arachidonic acid via the cyclooxygenase pathway. First, an intermediate prostaglandin $\mathrm{H}_{2}\left(\mathrm{PGH}_{2}\right)$ is generated, which serves as a substrate for various synthases that form $\mathrm{PGD}_{2}, \mathrm{PGE}_{2}, \mathrm{PGI}_{2}, \mathrm{PGF}_{2 \alpha}$, and thromboxane [154]. Since the biology of prostaglandins and their targeting has been thoroughly reviewed recently by Lee et al. [194], this section provides only a cursory overview of previously published studies.

\subsubsection{Prostaglandin $\mathrm{D}_{2}$}

In the peripheral tissues, $\mathrm{PGD}_{2}$ is metabolized from $\mathrm{PGH}_{2}$ via the action of hematopoietic PGD synthase (hPGDS) $[195,196] . \mathrm{PGD}_{2}$ is reported to bind to two receptors DP1 and DP2 (also called chemoattractant homologous molecule expressed on $\mathrm{T}_{\mathrm{H}} 2$ cellsCRTH2) [197]. Both, the hPGDS and the receptors DP1 and DP2 are expressed by eosinophils $[132,198,199]$. Hence, eosinophils are able to produce and release $\mathrm{PGD}_{2}$ following stimulation [200]. Furthermore, eosinophils isolated from patients with aspirin exacerbated respiratory disease produce more $\mathrm{PGD}_{2}$ and express higher levels of hPGDS [201]. Similarly, higher hPGDS expression was observed in tissue from allergic rhinitis patients [202]. Finally, in a study published recently, corticosteroid treatment was shown to downregulate hPGDS and DP2 expression in aspirin exacerbated respiratory disease [203].

The multiple pro-inflammatory actions of $\mathrm{PGD}_{2}$ on its receptors DP1 and DP2 on eosinophils have been reviewed in detail by Peinhaupt et al. [197]. Briefly, binding of $\mathrm{PGD}_{2}$ or selective agonists to DP2 promotes $\mathrm{Ca}^{2+}$ flux, CD11b upregulation, migration and degranulation of human eosinophils $[118,119]$. Moreover, by acting via DP2, PGD $_{2}$ was found to prime eosinophils for other chemoattractants [120,121]. Activation of DP1 on eosinophils has in turn been studied in much less detail. A study by Gervais et al. showed that activation of DP1 on eosinophils prolongs their survival, whereas Peinhaupt et al. elucidated that the mechanism behind prolonged survival involves the induction of serum response element and pro-inflammatory genes [118,122]. Moreover, DP1 was found to enhance and modulate DP2 signaling and the co-operation of both receptors was shown to be crucial for efficient $\mathrm{LTC}_{4}$ secretion from eosinophils $[123,204]$.

For targeting the $\mathrm{PGD}_{2}$ pathway in allergic inflammation, mainly DP2 antagonists have been used, while only a few reports studied the effects of hPGDS inhibition. In a recent preclinical study of allergic rhinitis, the hPGDS inhibitor TAS-205 in combination with montelukast showed a significant additive inhibitory effect on eosinophil infiltration and nasal obstruction in the late phase, when compared to treatment with either active agent alone [73]. Moreover, another orally-bioavailable hPGDS inhibitor (HQL-79) was found to reduce airway inflammation in an ovalbumin-model of allergic inflammation [72]. Currently, an ongoing phase I clinical study is assessing the safety and pharmacokinetics of the reversible hPGDS inhibitor ZL-2102 for treatment of chronic obstructive pulmonary disease, idiopathic pulmonary fibrosis, and asthma (NCT02397005).

In contrast, DP receptors have been studied in detail in multiple clinical studies with mixed results $[202,205,206]$. Fevipiprant (an oral antagonist of the DP2 receptor) was tested in two phase III clinical studies (LUSTER-1 and LUSTER-2), but neither of the two clinical trials demonstrated statistically significant reductions in asthma exacerbations [74]. Similarly, another DP2 antagonist AZD1981 recently showed no added benefit as an addon therapy to inhaled corticosteroids and long-acting $\beta 2$ agonists in atopic asthma [207]. 
However, promising results of the DP1 antagonist ONO-4053 for the treatment of allergic rhinitis were obtained in a phase II clinical study [75].

\subsubsection{Prostaglandin $\mathrm{E}_{2}$}

$\mathrm{PGE}_{2}$ is produced from $\mathrm{PGH}_{2}$ by the action of prostaglandin $\mathrm{E}$ synthases [198]. While $\mathrm{PGE}_{2}$ (together with $\mathrm{LXA}_{4}$ and $\mathrm{PGI}_{2}$ ) is hypothesized to be an arachidonic acid-derived pro-resolving mediator [199], it also shows pro-inflammatory activities such as exacerbating autoimmune diseases [208]. Moreover, due to its immunosuppressive actions, $\mathrm{PGE}_{2}$ is considered detrimental in the tumor microenvironment [209-211]. On one hand levels of $\mathrm{PGE}_{2}$ were found to be increased in asthma and non-asthmatic eosinophilic bronchitis, while on the other hand, Aggarwal et al. reported an inverse relationship between $\mathrm{PGE}_{2}$ levels and eosinophil sputum counts $[205,206,212] . \mathrm{PGE}_{2}$ is reported to activate four receptors (EP1, EP2, EP3 and EP4). Of those, eosinophils were reported to express EP2 and EP4 receptors $[78,213,214]$. Of note, Durchschein et al. recently demonstrated a decreased expression of EP2 and EP4 receptors on blood eosinophils in a small cohort of patients with eosinophilic esophagitis [215].

Upon binding to EP2 and EP4 on eosinophils, $\mathrm{PGE}_{2}$ inhibits their effector responses such as chemotaxis and degranulation as well as CD11b upregulation [76,124]. Surprisingly, $\mathrm{PGE}_{2}$ was also found to promote survival of eosinophils $[125,126]$. By using an EP4 agonist, it was further demonstrated that the $\mathrm{PGE}_{2}-\mathrm{EP} 4$ axis is important for the interactions of eosinophils with endothelial cells [216]. Finally, the EP2 receptor agonist butaprost was shown to attenuate airway inflammation in a ovalbumin model of allergic airway inflammation [76], and in two recent studies investigating mast cell-mediated allergic responses $[77,217]$. In mild asthmatic patients, inhalation of $\mathrm{PGE}_{2}$ prior to allergen challenge significantly improved lung function parameters and attenuated airway inflammation and reduced eosinophil counts in sputum [127]. Although $\mathrm{PGE}_{2}$ suppresses eosinophil activation, $\mathrm{PGE}_{2}$ can activate other immune cell types and therefore may promote the development of diseases such as atherosclerosis, rheumatoid arthritis, cancer, and influenza virus infections [218-222]. Moreover, a recent study established a connection between $\mathrm{PGE}_{2}$-induced impaired immune response, male sex, and the risk of cardiovascular complications in COVID-19 patients [213]. Thus, application of this multifaceted lipid mediator or its analogues would most likely result in numerous side-effects.

\subsubsection{Prostaglandin $\mathrm{I}_{2}$-Prostacyclin}

Prostacyclin $\left(\mathrm{PGI}_{2}\right)$ is synthesized from $\mathrm{PGH}_{2}$ via the action of prostaglandin I synthase [214]. It is mainly produced in the vasculature, where it was found to be vasodilatatory and anti-aggregatory and is therefore considered an important player in cardiovascular health $[214,223]$. A stable inhaled analogue of $\mathrm{PGI}_{2}-\mathrm{iloprost}$ is currently indicated for treatment of pulmonary arterial hypertension [214,224]. Moreover, a recent multi-center clinical study investigated its beneficial effects as an add-on therapy in mechanically ventilated COVID-19 patients (NCT04420741) [225]. Although the beneficial effects of $\mathrm{PGI}_{2}$ on the vasculature have been thoroughly studied in the past, its immunomodulatory functions have only recently been recognized and are currently being studied in more detail [214].

Comparable to the effects of $\mathrm{PGE}_{2}, \mathrm{PGI}_{2}$ was also reported to inhibit eosinophil activation. Specifically, $\mathrm{PGI}_{2}$ as well as iloprost were discovered to inhibit the migration of guinea pig bone marrow eosinophils and human eosinophils via the $\mathrm{PGI}_{2}$ receptor IP $[79,128]$. Endothelium-derived $\mathrm{PGI}_{2}$ was found to modulate eosinophil-endothelial interaction and to affect eosinophil adhesion and transmigration, while promoting the barrier function in endothelial cells [128].

Overall, IP-receptor deficient mice exhibited exacerbated allergic inflammatory responses and airway remodeling, while inhalation of iloprost improved features of asthma in a preclinical model $[80,226,227]$. Recently, the use of IP-receptor deficient mice further elucidated the role of $\mathrm{PGI}_{2}$ in influencing the numbers and characteristics of natural 
killer cells, which limit lung innate lymphoid cells type 2 (ILC2s), preventing house dust mite-induced allergic inflammation [228].

\subsection{5-Oxo-8,11,14-Eicosatrienoic Acid (5-Oxo-ETE)}

5-oxo-ETE is a lipid mediator produced from AA via oxidation of the 5-LO intermediate 5-HETE by the 5-hydroxyeicosanoid dehydrogenase (5-HEDH). 5-HETE has been shown to induce neutrophil and eosinophil migration and activation in vitro and in vivo and increased 5-HETE release has been observed in alveolar macrophages from asthmatic patients [229]. Compared to other eicosanoids, 5-HETE possesses only weak biological activity itself, but is further oxidized to 5-oxo-ETE, a potent chemoattractant for eosinophils and neutrophils. The precise biosynthesis pathway of 5-oxo-ETE has been reviewed in detail by Powell et al. [230]. It has been shown that concentration of 5-oxo-ETE is increased in exhaled breath condensates and correlates with the number of peripheral blood eosinophils following allergen challenge in patients sensitized to house dust mite [231]. Moreover, 5-oxo-ETE derived from nasal epithelial cells was shown to upregulate eosinophil cationic protein in eosinophils in nasal polyps [108]. Finally, an intradermal application of 5-oxoETE induced potent infiltration of both eosinophils and neutrophils into the skin, whereby infiltration of eosinophils was more than three times higher in asthmatic patients compared to control subjects [107].

5-HETE and 5-oxo-ETE were so far reported to bind to and activate the GPCR OXER1 (also known as TG1019) [232,233]. Expression of the receptor was detected on eosinophils, neutrophils, bronchoalveolar macrophages, basophils, monocytes, and a variety of cancer cell lines, with the highest expression on eosinophils [106,232,234]. Binding of 5-oxo-ETE to its receptor on eosinophils was reported to result in potent chemotaxis (highest among lipid mediators), increased cell activation, and degranulation $[104,105,226,227,235,236]$. Moreover, priming of eosinophils with granulocyte-macrophage colony-stimulating factor enhances 5-oxo-ETE-induced eosinophil degranulation [236]. 5-oxo-ETE can additionally induce the migration of eosinophils across endothelial cell layers and across the basement membrane by activating matrix metalloproteinases MMP-7 and MMP-9, which can degrade matrix components and ease the passage of eosinophils [237,238].

In contrast to research in the field of leukotrienes and prostaglandins, very few studies have been performed on 5-oxo-ETE and its receptor. This is mainly due to the absence of 5-oxo-ETE receptor and its orthologs in rodents limiting preclinical research. However, recently novel selective 5-oxo-receptor antagonists were characterized and tested $[82,239,240]$. Of those, S-Y048, which is highly potent and orally bioavailable, demonstrated a significant inhibition of eosinophil infiltration into the skin in response to intradermally administered 5-oxo-ETE and house dust mite in cynomolgus monkeys [80]. Thus, targeting of 5-oxo-ETE shows potential as a novel therapy for asthma and eosinophil-associated diseases [241].

\section{Phospholipase C (PLC) Cleavage Products: Diacylglycerol (DAG) and Inositol 1,4,5-Trisphosphate $\left(\mathrm{IP}_{3}\right)$ and Endocannabinoids}

Phospholipase $\mathrm{C}$ hydrolyzes phosphatidylinositol 4,5-bisphosphate $\left(\mathrm{PIP}_{2}\right)$ at the phosphodiester bond between the glycerol backbone and the phosphate group. PLC produces diacylglycerol (DAG) and inositol 1,4,5-trisphosphate $\left(\mathrm{IP}_{3}\right)$ in response to cell activation signals [242]. Both $\mathrm{IP}_{3}$ and DAG are crucial molecules regulating signal transduction during cell activation and play a role in development of various diseases [243]. As such, PLC activation was shown to be involved in PAF-induced eosinophil degranulation and leukotriene secretion $[244,245]$. Synthetic alkyl ether lipids such as edelfosine and miltefosine are inhibitors of PLC activity. Following eosinophil stimulation, both alkyl ether lipids were shown to inhibit eosinophil granule release and $\mathrm{Ca}^{2+}$ flux, resulting from an increase in $\mathrm{IP}_{3}$ concentration $[57,246,247]$.

In contrast to soluble $\mathrm{IP}_{3}$, DAG remains bound at the cell membrane, where diacylglycerol lipase may hydrolyze it to 2-arachidonolyglycerol (2-AG) [248]. Eosinophils were recently discovered to express high levels of DAG lipase in contrast to neutrophils 
and lymphocytes, indicating the importance of the pathway for 2-AG synthesis in these cells [249].

2-AG belongs to the endocannabinoid system consisting of endocannabinoid ligands, endocannabinoid receptors, and enzymes related to their synthesis and degradation. While many studies depict the roles of the endocannabinoid system in allergic diseases, their actual contribution remains controversial [250]. 2-AG binds to and activates GPCRs such as the cannabinoid receptor 1 and $2\left(\mathrm{CB}_{1}, \mathrm{CB}_{2}\right)$. Moreover, 2-AG may be converted to arachidonic acid via the monoacylglycerol lipase (MGL) pathway leading to eicosanoid production [250]. Human leukocytes were found to differentially express $C_{1}$ and $C_{2}$ receptors as well as MGL [251-253]. Eosinophils, in particular, were shown to express MGL and $\mathrm{CB}_{2}$ receptor $[117,251,253]$ and were found to migrate towards 2-AG [254,255]. Furthermore, the expression of the $\mathrm{CB}_{2}$ receptor is increased in eosinophils from symptomatic allergic donors and upregulated following ovalbumin challenge in mice, while $\mathrm{CB}_{1}$ expression was found to be upregulated in tonsils from allergic rhinitis patients $[117,256,257]$. In addition, their endogenous ligand 2-AG was found to be increased following challenge in both a contact dermatitis and dust mite antigen-induced dermatitis mouse model [64,258].

The $\mathrm{CB}_{2}$ receptor is known to mediate anti-inflammatory effects in many diseases, such as atherosclerosis and stress-induced neuroinflammation [239,240,259,260]. However, its activation on eosinophils surprisingly resulted in increased eosinophil reactivity and exacerbation of allergen-induced inflammation $[103,258]$. The $\mathrm{CB}_{2}$ receptor agonist S-777469 exhibited efficacy for treatment of atopic dermatitis in preclinical studies, supposedly via blockade of endogenous 2-AG binding to $\mathrm{CB}_{2}$. Unfortunately, results from a phase $\mathrm{Ib} / \mathrm{IIa}$ clinical study in patients (NCT00697710) have not yet been made available [64].

Another possibility of targeting the 2-AG metabolism in eosinophils arises from specific blockade of its hydrolyzing enzyme MGL. A recent report by Abohalaka et al. suggested that inhibition of MGL with the specific inhibitor JZL184 ameliorates lipopolysaccharide-induced airway inflammation [65]. Similar findings were observed in human eosinophils in vitro, where MGL inhibition prevented the migration of primed eosinophils in response to 2-AG, suggesting potential anti-inflammatory actions of MGL inhibitors in lung inflammation and allergy [66]. The involvement of the endocannabinoid system in allergic diseases was comprehensively described by Angelina et al. in a recent Collegium Internationale Allergologicum update [250].

\section{Phospholipase D Cleavage Product: Lysophosphatidic Acid (LPA)}

Phospholipases D cleave the phospholipid molecule yielding the phosphatidic acid and the phospholipid headgroup (e.g., choline, ethanolamine ... ). Consequently, phosphatidic acid can be further metabolized into lysophosphatidic acid (LPA). Another pathway resulting in LPA production involves the hydrolysis of LPC via lysophospholipase D (also called autotaxin) [261]. Multiple studies suggest that both LPA concentration (specifically polyunsaturated species) and autotaxin levels and activity are increased in allergic diseases and asthma [67,261-263]. Moreover, serum autotaxin levels were found to correlate with pruritus in patients with atopic dermatitis [246]. Park et al. reported that autotaxin overexpressing mice exhibited an aggravated asthmatic phenotype, while blocking the enzymatic activity of autotaxin attenuated allergic inflammation [67]. A small molecule inhibitor of autotaxin (GLPG1690, ziritaxestat) was advanced to phase 3 clinical trials for idiopathic pulmonary fibrosis and phase 2 for systemic sclerosis, but all trials were discontinued in February 2021 (NCT03711162, NCT03976648) [247]. So far, autotaxin inhibition in allergy has not been tested in clinical trials.

Lysophosphatidic acid is reported to bind to and activate six different GPCRs (LPA $1-6)$ the so-called canonical LPA receptors [261,264]. The LPA receptor expression varies between immune cells, for instance eosinophils were reported to express $\mathrm{LPA}_{1}$ and $\mathrm{LPA}_{3}$ receptor, but lack $\mathrm{LPA}_{2}$ receptor expression $[113,264]$. Stimulation of human eosinophils with LPA resulted in chemotaxis, reactive oxygen production, $\mathrm{Ca}^{2+}$ flux, and CD11b upregulation [113]. Furthermore, in vivo application of LPA enhanced infiltration and action of guinea pig 
eosinophils [114]. Most studies investigating LPA receptor antagonism in allergic airway diseases focus on targeting $\mathrm{LPA}_{2}$, which reportedly suppresses airway hyperresponsiveness and immune cell infiltration in the BALF and lung tissue $[67,251,264,265]$. However, a recent study implicates the involvement of LPA receptors 1 and 3 in a neural mechanism involving LPA- induced carotid body activation, leading to acute bronchoconstriction [68]. Moreover, blockade of LPA receptors 1 and 3 (with the specific antagonist ki16425) reduced bradykinin-induced asthmatic bronchoconstriction and suppressed respiratory distress following allergen challenge [68].

Additionally, LPA is reported to activate non-canonical receptors such as peroxisome proliferator-activated receptor (PPAR)- $\gamma$, vanilloid receptor 1 channel as well as the receptor for advanced glycosylation products (RAGE) [252,253,256,257]. RAGE has been recently identified as a major mediator in inflammatory lung diseases, including asthma [266-268]. In fact, RAGE has been pinpointed as a critical mediator of $\mathrm{T}_{\mathrm{H}} 2$ signaling in the lung (using either small molecule inhibitors (e.g., FPS-ZM1) or mice lacking RAGE expression) $[69,269]$. In particular, application of the antagonist FPS-ZM1 drastically inhibited eosinophil infiltration following intranasal IL-5/IL-13 application [69]. RAGE is highly expressed on Type 1 alveolar epithelial cells as well as on immune cells such as eosinophils, promoting their survival [266,270-272]. Intriguingly, even though Dyer et al. demonstrated high RAGE expression on eosinophils, they could not observe receptor activation following activation with its natural ligand high-mobility group box 1 protein [272].

The role of autotaxin and LPA in immune regulation and asthma was recently reviewed by Kim et al. [252]. In their excellent review, the authors address an unmet need for available transgenic animal models to study cell-specific LPA production as well as LPA receptor expression and involvement in asthma and other immune diseases.

\section{Non-Enzymatic Lipid Peroxidation}

Exposure to allergic stimuli as well as gaseous pollutants, chemicals, viruses, and bacteria leads to the recruitment of eosinophils and neutrophils, which have a high capacity for reactive oxygen species (ROS) production. Activation of these inflammatory cells leads to the so-called 'respiratory burst', which is characterized by an increased production of $\mathrm{O}_{2} \cdot{ }^{-}, \cdot \mathrm{OH}, \mathrm{H}_{2} \mathrm{O}_{2}$, hypochlorous and hypobromous acids [273-275]. This increased oxidative stress is associated with asthma pathophysiology, including airway hyperactivity and remodeling [276-280].

Eosinophils are reported to release up to two times more ROS compared to neutrophils [281]. Moreover, eosinophils express high levels of eosinophil peroxidase (EPO), which catalyzes many oxidative reactions and generates hypobromous acid capable of brominating protein tyrosine residues $[282,283]$. Furthermore, eosinophils from asthmatics were found to produce more ROS compared to healthy donors. [284,285] contributing to disease development through oxidation of DNA, proteins, and lipids [286]. Interestingly, ROS production is crucial for eosinophil extracellular trap release and the resulting airway damage [287].

Lipid peroxidation is generally considered as the main molecular mechanism involved in oxidative damage to cell structures. PUFAs, in particular, are prone to non-enzymatic lipid peroxidation due to the presence of the double bond near the methylene bridge, leading to autooxidation by the attack of free radicals [288]. Bioactive metabolites such as isoprostanes, dihomo-isoprostanes, isofurans, and neuroprostanes are formed by nonenzymatic PUFA peroxidation [289]. These mediators participate in many pathophysiological processes and are considered as biomarkers of oxidative stress [289-291]. Among these, especially stable F2-isoprostanes were found to be increased following allergen challenge in mice and humans as well as in asthmatic subjects [292-297].

Eosinophils contribute to oxidative stress in mild asthma and targeting oxidative stress could be considered as a treatment option during asthma exacerbations [298]. Preclinical data from Silveira et al. demonstrated that the ROS inhibitors N-acetylcysteine or diphenyleneiodonium reduced eosinophil extracellular trap formation by eosinophils and 
ameliorated airway inflammation [287]. Antioxidant supplementation with free radical scavengers, such as vitamin $C$ or vitamin $E$ has also been extensively studied in asthma and allergic diseases [299-301]. However, conflicting reports exist on the potential benefits of vitamin E supplementation, which acts as an inhibitor of the propagation cycle of lipid peroxidation [302-304]. This was partly explained by the report from Berdnikovs at al., which showed opposing functions of vitamin E isoforms on eosinophil and other immune cell recruitment in an experimental asthma model [305].

\section{Conclusions}

Phospholipases produce multiple reactive cleavage products, including lysophospholipids, polyunsaturated fatty acids, and eicosanoids. The highly complex network of lipids and lipid mediators modulates a variety of eosinophil functions in health and disease. The discovery of novel subclasses of lipid mediators and their receptors opens new possibilities for drug targeting. Because lipid mediator levels and the activity of their metabolizing enzymes are dysregulated in allergic inflammation and eosinophil-associated diseases, they offer a unique opportunity to target the over-activation and 'pro-inflammatory' phenotype of eosinophils. Importantly, this could be achieved without compromising the survival and functions of tissue-resident and homeostatic eosinophils. Fortunately, most lipid mediators function through GPCRs, which are highly drug-responsive receptors that can be readily targeted with orally bioavailable small molecule drugs.

Author Contributions: Conceptualization, E.K. and G.M.; writing-original draft preparation, E.K. and E.M.S.; writing-review and editing, G.M. and E.M.S.; visualization, E.K.; supervision, G.M. All authors have read and agreed to the published version of the manuscript.

Funding: This work was supported by the Austrian Science Fund (FWF) (W1241) (01/10/2016).

Acknowledgments: Open Access Funding by the Austrian Science Fund (FWF). Figures were created with Biorender.com.

Conflicts of Interest: The authors declare no conflict of interest.

\section{References}

1. Wen, T.; Rothenberg, M.E.; Cells, R.E. The Regulatory Function of Eosinophils. Microbiol. Spectr. 2016, 4, 1-12.

2. Lee, J.J.; Jacobsen, E.A.; McGarry, M.P.; Schleimer, R.P.; Lee, N.A. Eosinophils in Health and Disease: The LIAR Hypothesis. Clin. Exp. Allergy 2010, 40, 563-575. [CrossRef]

3. Rothenberg, M.E.; Hogan, S.P. The Eosinophil. Annu. Rev. Immunol. 2006, 24, 147-174. [CrossRef] [PubMed]

4. Fulkerson, P.C.; Rothenberg, M.E. Targeting Eosinophils in Allergy, Inflammation and Beyond. Nat. Rev. Drug Discov. 2013, 12, 117-129. [CrossRef] [PubMed]

5. Kariyawasam, H.H.; Robinson, D.S. The Role of Eosinophils in Airway Tissue Remodelling in Asthma. Curr. Opin. Immunol. 2007, 19, 681-686. [CrossRef]

6. Acharya, K.R.; Ackerman, S.J. Eosinophil Granule Proteins: Form and Function. J. Biol. Chem. 2014, 289, 17406-17415. [CrossRef]

7. Legrand, F.; Klion, A.D. Biologic Therapies Targeting Eosinophils: Current Status and Future Prospects. J. Allergy Clin. Immunol. Pract. 2015, 3, 167-174. [CrossRef] [PubMed]

8. $\quad$ Busse, W.W.; Bleecker, E.R.; FitzGerald, J.M.; Ferguson, G.T.; Barker, P.; Sproule, S.; Olsson, R.F.; Martin, U.J.; Goldman, M.; Yañez, A.; et al. Long-Term Safety and Efficacy of Benralizumab in Patients with Severe, Uncontrolled Asthma: 1-Year Results from the BORA Phase 3 Extension Trial. Lancet Respir. Med. 2019, 7, 46-59. [CrossRef]

9. Dellon, E.S.; Peterson, K.A.; Murray, J.A.; Falk, G.W.; Gonsalves, N.; Chehade, M.; Genta, R.M.; Leung, J.; Khoury, P.; Klion, A.D.; et al. Anti-Siglec-8 Antibody for Eosinophilic Gastritis and Duodenitis. N. Engl. J. Med. 2020, 383, 1624-1634. [CrossRef] [PubMed]

10. Reichman, H.; Itan, M.; Rozenberg, P.; Yarmolovski, T.; Brazowski, E.; Varol, C.; Gluck, N.; Shapira, S.; Arber, N.; Qimron, U.; et al Activated Eosinophils Exert Antitumorigenic Activities in Colorectal Cancer. Cancer Immunol. Res. 2019, 7, 388-400. [CrossRef]

11. Kienzl, M.; Hasenoehrl, C.; Valadez-Cosmes, P.; Maitz, K.; Sarsembayeva, A.; Sturm, E.; Heinemann, A.; Kargl, J.; Schicho, R. IL-33 Reduces Tumor Growth in Models of Colorectal Cancer with the Help of Eosinophils. Oncoimmunology 2020, 9, 1776059. [CrossRef]

12. Munitz, A.; Hogan, S.P. Alarming Eosinophils to Combat Tumors. Nat. Immunol. 2019, 20, 250-252. [CrossRef]

13. Grisaru-Tal, S.; Itan, M.; Grass, D.G.; Torres-Roca, J.; Eschrich, S.A.; Gordon, Y.; Dolitzky, A.; Hazut, I.; Avlas, S.; Jacobsen, E.A.; et al. Primary Tumors from Mucosal Barrier Organs Drive Unique Eosinophil Infiltration Patterns and Clinical Associations. Oncoimmunology 2021, 10, 1859732. [CrossRef] 
14. Wang, Y.; Yang, Y.; Wang, M.; Wang, S.; Jeong, J.-M.; Xu, L.; Wen, Y.; Emontzpohl, C.; Atkins, C.L.; Duong, K.; et al. Eosinophils Attenuate Hepatic Ischemia-Reperfusion Injury in Mice through ST2-Dependent IL-13 Production. Sci. Transl. Med. 2021, 13, eabb6576. [CrossRef]

15. Liu, J.; Yang, C.; Liu, T.; Deng, Z.; Fang, W.; Zhang, X.; Li, J.; Huang, Q.; Liu, C.; Wang, Y.; et al. Eosinophils Improve Cardiac Function after Myocardial Infarction. Nat. Commun. 2020, 11, 1-15. [CrossRef]

16. Ding, R.; Yang, Z.; Huang, D.; Wang, Y.; Li, X.; Zhou, X.; Yan, L.; Lu, W.; Zhang, Z. Identification of Parameters in Routine Blood and Coagulation Tests Related to the Severity of COVID-19. Int. J. Med. Sci. 2021, 18, 1207-1215. [CrossRef]

17. Nair, A.P.; Soliman, A.; Al Masalamani, M.A.; De Sanctis, V.; Nashwan, A.J.; Sasi, S.; Ali, E.A.; Hassan, O.A.; Iqbal, F.M.; Yassin, M.A. Clinical Outcome of Eosinophilia in Patients with Covid-19: A Controlled Study. Acta Biomed. 2020, 91, 1-10.

18. Cazzaniga, M.; Fumagalli, L.; D’Angelo, L.; Cerino, M.; Bonfanti, G.; Fumagalli, R.; Schiavo, G.; Lorini, C.; Lainu, E.; Terragni, S.; et al. Eosinopenia Is a Reliable Marker of Severe Disease and Unfavorable Outcome in Patients with COVID-19 Pneumonia. Int. J. Clin. Pract. 2021, e14047. [CrossRef]

19. Outh, R.; Boutin, C.; Gueudet, P.; Suzuki, M.; Saada, M.; Aumaître, H. Eosinopenia <100/ML as a Marker of Active COVID-19: An Observational Prospective Study. J. Microbiol. Immunol. Infect. 2021, 54, 61-68. [CrossRef] [PubMed]

20. Georgakopoulou, V.E.; Garmpis, N.; Damaskos, C.; Valsami, S.; Dimitroulis, D.; Diamantis, E.; Farmaki, P.; Papageorgiou, C.V.; Makrodimitri, S.; Gravvanis, N.; et al. The Impact of Peripheral Eosinophil Counts and Eosinophil to Lymphocyte Ratio (ELR) in the Clinical Course of COVID-19 Patients: A Retrospective Study. In Vivo 2021, 35, 641-648. [CrossRef] [PubMed]

21. Ferastraoaru, D.; Hudes, G.; Jerschow, E.; Jariwala, S.; Karagic, M.; de Vos, G.; Rosenstreich, D.; Ramesh, M. Eosinophilia in Asthma Patients Is Protective Against Severe COVID-19 Illness. J. Allergy Clin. Immunol. Pract. 2021, 9, 1152-1162. [CrossRef] [PubMed]

22. Simon, H.U.; Yousefi, S.; Germic, N.; Arnold, I.C.; Haczku, A.; Karaulov, A.V.; Simon, D.; Rosenberg, H.F. The Cellular Functions of Eosinophils: Collegium Internationale Allergologicum (CIA) Update 2020. Int. Arch. Allergy Immunol. 2020, 181, 11-23. [CrossRef]

23. Sokolowska, M.; Stefanska, J.; Wodz-Naskiewicz, K.; Cieslak, M.; Pawliczak, R. Cytosolic Phospholipase A2 Group IVA Is Overexpressed in Patients with Persistent Asthma and Regulated by the Promoter Microsatellites. J. Allergy Clin. Immunol. 2010, 125, 1393-1395. [CrossRef]

24. Bowton, D.L.; Seeds, M.C.; Fasano, M.B.; Goldsmith, B.; Bass, D.A. Phospholipase A2 and Arachidonate Increase in Bronchoalveolar Lavage Fluid after Inhaled Antigen Challenge in Asthmatics. Am. J. Respir. Crit. Care Med. 1997, 155, 421-425. [CrossRef] [PubMed]

25. Blom, M.; Tool, A.T.J.; Wever, P.C.; Wolbink, G.J.; Brouwer, M.C.; Calafat, J.; Egesten, A.; Knol, E.F.; Hack, C.E.; Roos, D.; et al. Human Eosinophils Express, Relative to Other Circulating Leukocytes, Large Amounts of Secretory 14-KD Phospholipase A2. Blood 1998, 91, 3037-3043.

26. Miyata, J.; Fukunaga, K.; Kawashima, Y.; Watanabe, T.; Saitoh, A.; Hirosaki, T.; Araki, Y.; Kikawada, T.; Betsuyaku, T.; Ohara, O.; et al. Dysregulated Fatty Acid Metabolism in Nasal Polyp-Derived Eosinophils from Patients with Chronic Rhinosinusitis. Allergy Eur. J. Allergy Clin. Immunol. 2019, 74, 1113-1124. [CrossRef]

27. Rodriguez-Perez, N.; Schiavi, E.; Frei, R.; Ferstl, R.; Wawrzyniak, P.; Smolinska, S.; Sokolowska, M.; Sievi, N.A.; Kohler, M.; Schmid-Grendelmeier, P.; et al. Altered Fatty Acid Metabolism and Reduced Stearoyl-Coenzyme a Desaturase Activity in Asthma. Allergy Eur. J. Allergy Clin. Immunol. 2017, 72, 1744-1752. [CrossRef] [PubMed]

28. Miyata, J.; Fukunaga, K.; Kawashima, Y.; Ohara, O.; Kawana, A.; Asano, K.; Arita, M. Dysregulated Metabolism of Polyunsaturated Fatty Acids in Eosinophilic Allergic Diseases. Prostaglandins Other Lipid Mediat. 2020, 150, 106477. [CrossRef]

29. Filkin, S.Y.; Lipkin, A.V.; Fedorov, A.N. Phospholipase Superfamily: Structure, Functions, and Biotechnological Applications. Biochemistry 2020, 85, 177-195. [CrossRef]

30. Aloulou, A.; Rahier, R.; Arhab, Y.; Noiriel, A.; Abousalham, A. Phospholipases: An overview. In Methods in Molecular Biology; Humana Press Inc.: Totowa, NJ, USA, 2018; Volume 1835, pp. 69-105.

31. Pniewska, E.; Pawliczak, R. The Involvement of Phospholipases A2 in Asthma and Chronic Obstructive Pulmonary Disease. Mediat. Inflamm. 2013, 2013. [CrossRef]

32. Burke, J.E.; Dennis, E.A. Phospholipase A 2 Structure/Function, Mechanism, and Signaling. J. Lipid Res. 2009, 50, S237. [CrossRef]

33. Dennis, E.A. Introduction to Thematic Review Series: Phospholipases: Central Role in Lipid Signaling and Disease. J. Lipid Res. 2015, 56, 1245-1247. [CrossRef] [PubMed]

34. White, S.R.; Strek, M.E.; Kulp, G.V.P.; Spaethe, S.M.; Burch, R.A.; Neeley, S.P.; Leff, A.R. Regulation of Human Eosinophil Degranulation and Activation by Endogenous Phospholipase A2. J. Clin. Investig. 1993, 91, 2118-2125. [CrossRef] [PubMed]

35. Triggiani, M.; Giannattasio, G.; Calabrese, C.; Loffredo, S.; Granata, F.; Fiorello, A.; Santini, M.; Gelb, M.H.; Marone, G. Lung Mast Cells Are a Source of Secreted Phospholipases A2. J. Allergy Clin. Immunol. 2009, 124, 558-565. [CrossRef] [PubMed]

36. Kertys, M.; Grendar, M.; Kosutova, P.; Mokra, D.; Mokry, J. Plasma Based Targeted Metabolomic Analysis Reveals Alterations of Phosphatidylcholines and Oxidative Stress Markers in Guinea Pig Model of Allergic Asthma. Biochim. Biophys. Acta Mol. Basis Dis. 2020, 1866, 165572. [CrossRef]

37. Nolin, J.D.; Lai, Y.; Ogden, H.L.; Manicone, A.M.; Murphy, R.C.; An, D.; Frevert, C.W.; Ghomashchi, F.; Naika, G.S.; Gelb, M.H.; et al. Secreted PLA2 Group X Orchestrates Innate and Adaptive Immune Responses to Inhaled Allergen. JCI Insight 2017, 2, e94929. [CrossRef] [PubMed] 
38. Ogden, H.L.; Lai, Y.; Nolin, J.D.; An, D.; Frevert, C.W.; Gelb, M.H.; Altemeier, W.A.; Hallstrand, T.S. Secreted Phospholipase A 2 Group X Acts as an Adjuvant for Type 2 Inflammation, Leading to an Allergen-Specific Immune Response in the Lung. J. Immunol. 2020, 204, 3097-3107. [CrossRef]

39. Henderson, W.R.; Chi, E.Y.; Bollinger, J.G.; Tien, Y.T.; Ye, X.; Castelli, L.; Rubtsov, Y.P.; Singer, A.G.; Chiang, G.K.S.; Nevalainen, T.; et al. Importance of Group X-Secreted Phospholipase A2 in Allergen-Induced Airway Inflammation and Remodeling in a Mouse Asthma Model. J. Exp. Med. 2007, 204, 865-877. [CrossRef]

40. Hallstrand, T.S.; Lai, Y.; Hooper, K.A.; Oslund, R.C.; Altemeier, W.A.; Matute-Bello, G.; Gelb, M.H. Endogenous Secreted Phospholipase A2 Group X Regulates Cysteinyl Leukotrienes Synthesis by Human Eosinophils. J. Allergy Clin. Immunol. 2016, 137, 268-277.e8. [CrossRef]

41. Lai, Y.; Oslund, R.C.; Bollinger, J.G.; Henderson, W.R.; Santana, L.F.; Altemeier, W.A.; Gelb, M.H.; Hallstrand, T.S. Eosinophil Cysteinyl Leukotriene Synthesis Mediated by Exogenous Secreted Phospholipase A2 Group X. J. Biol. Chem. 2010, 285, 4149141500. [CrossRef] [PubMed]

42. Henderson, W.R.; Oslund, R.C.; Bollinger, J.G.; Ye, X.; Tien, Y.T.; Xue, J.; Gelb, M.H. Blockade of Human Group X Secreted Phospholipase A 2 (GX-SPLA 2)-Induced Airway Inflammation and Hyperresponsiveness in a Mouse Asthma Model by a Selective GX-SPLA 2 Inhibitor. J. Biol. Chem. 2011, 286, 28049-28055. [CrossRef] [PubMed]

43. Muñoz, N.M.; Meliton, A.Y.; Arm, J.P.; Bonventre, J.V.; Cho, W.; Leff, A.R. Deletion of Secretory Group V Phospholipase A2 Attenuates Cell Migration and Airway Hyperresponsiveness in Immunosensitized Mice. J. Immunol. 2007, 179, 4800-4807. [CrossRef] [PubMed]

44. Giannattasio, G.; Fujioka, D.; Xing, W.; Katz, H.R.; Boyce, J.A.; Balestrieri, B. Group V Secretory Phospholipase A2 Reveals Its Role in House Dust Mite-Induced Allergic Pulmonary Inflammation by Regulation of Dendritic Cell Function. J. Immunol. 2010, 185, 4430-4438. [CrossRef]

45. Yamaguchi, M.; Samuchiwal, S.K.; Quehenberger, O.; Boyce, J.A.; Balestrieri, B. Macrophages Regulate Lung ILC2 Activation via Pla2g5-Dependent Mechanisms. Mucosal Immunol. 2018, 11, 615-626. [CrossRef]

46. Muñoz, N.M.; Kim, Y.J.; Meliton, A.Y.; Kim, K.P.; Han, S.K.; Boetticher, E.; O’Leary, E.; Myou, S.; Zhu, X.; Bonventre, J.V.; et al. Human Group V Phospholipase A2 Induces Group IVA Phospholipase A2-Independent Cysteinyl Leukotriene Synthesis in Human Eosinophils. J. Biol. Chem. 2003, 278, 38813-38820. [CrossRef]

47. Myou, S.; Sano, H.; Fujimura, M.; Zhu, X.; Kurashima, K.; Kita, T.; Nakao, S.; Nonomura, A.; Shioya, T.; Kim, K.P.; et al. Blockade of Eosinophil Migration and Airway Hyperresponsiveness by CPLA2-Inhibition. Nat. Immunol. 2001, 2, 145-149. [CrossRef] [PubMed]

48. Yanes, D.A.; Mosser-Goldfarb, J.L. Emerging Therapies for Atopic Dermatitis: The Prostaglandin/Leukotriene Pathway. J. Am. Acad. Dermatol. 2018, 78, S71-S75. [CrossRef]

49. Kokotou, M.G.; Galiatsatou, G.; Magrioti, V.; Koutoulogenis, G.; Barbayianni, E.; Limnios, D.; Mouchlis, V.D.; Satpathy, B.; Navratil, A.; Dennis, E.A.; et al. 2-Oxoesters: A Novel Class of Potent and Selective Inhibitors of Cytosolic Group IVA Phospholipase A2 Sci. Rep. 2017, 7, 1-16. [CrossRef]

50. Koutoulogenis, G.S.; Kokotou, M.G.; Hayashi, D.; Mouchlis, V.D.; Dennis, E.A.; Kokotos, G. 2-Oxoester Phospholipase A2 Inhibitors with Enhanced Metabolic Stability. Biomolecules 2020, 10, 491. [CrossRef]

51. Henderson, W.R.; Lu, J.; Poole, K.M.; Dietsch, G.N.; Chi, E.Y. Recombinant Human Platelet-Activating Factor-Acetylhydrolase Inhibits Airway Inflammation and Hyperreactivity in Mouse Asthma Model. J. Immunol. 2000, 164, 3360-3367. [CrossRef]

52. Henig, N.R.; Aitken, M.L.; Liu, M.C.; Yu, A.S.; Henderson, W.R. Effect of Recombinant Human Platelet-Activating FactorAcetylhydrolase on Allergen-Induced Asthmatic Responses. Am. J. Respir. Crit. Care Med. 2000, 162, 523-527. [CrossRef]

53. Maiti, R.; Rahman, J.; Jaida, J.; Allala, U.; Palani, A. Rupatadine and Levocetirizine for Seasonal Allergic Rhinitis: A Comparative Study of Efficacy and Safety. Arch. Otolaryngol. Head Neck Surg. 2010, 136, 796-800. [CrossRef]

54. Metz, M.; Maurer, M. Rupatadine for the Treatment of Allergic Rhinitis and Urticaria. Expert Rev. Clin. Immunol. 2011, 7, 15-20. [CrossRef]

55. Knuplez, E.; Kienzl, M.; Trakaki, A.; Schicho, R.; Heinemann, A.; Sturm, E.M.; Marsche, G. The Anti-parasitic Drug Miltefosine Suppresses Human Eosinophil Activation and Ameliorates Murine Allergic Inflammation In Vivo. Br. J. Pharmacol. 2021, 178, 1234-1248. [CrossRef] [PubMed]

56. Magerl, M.; Rother, M.; Bieber, T.; Biedermann, T.; Brasch, J.; Dominicus, R.; Hunzelmann, N.; Jakob, T.; Mahler, V.; Popp, G.; et al. Randomized, Double-Blind, Placebo-Controlled Study of Safety and Efficacy of Miltefosine in Antihistamine-Resistant Chronic Spontaneous Urticaria. J. Eur. Acad. Dermatol. Venereol. 2013, 27, e363-e369. [CrossRef]

57. Sato, M.; Aoki-Saito, H.; Fukuda, H.; Ikeda, H.; Koga, Y.; Yatomi, M.; Tsurumaki, H.; Maeno, T.; Saito, T.; Nakakura, T.; et al. Resolvin E3 Attenuates Allergic Airway Inflammation via the Interleukin-23-Interleukin-17A Pathway. FASEB J. 2019, 33, 12750-12759. [CrossRef]

58. Fukuda, H.; Ikeda, H.; Muromoto, R.; Hirashima, K.; Ishimura, K.; Fujiwara, K.; Aoki-Saito, H.; Hisada, T.; Watanabe, M.; Ishihara, J.; et al. Synthesis of Resolvin E3, a Proresolving Lipid Mediator, and Its Deoxy Derivatives: Identification of 18-Deoxy-Resolvin E3 as a Potent Anti-Inflammatory Agent. J. Org. Chem. 2020, 85, 14190-14200. [CrossRef] [PubMed]

59. Bang, S.; Xie, Y.K.; Zhang, Z.J.; Wang, Z.; Xu, Z.Z.; Ji, R.R. GPR37 Regulates Macrophage Phagocytosis and Resolution of Inflammatory Pain. J. Clin. Investig. 2018, 128, 3568-3582. [CrossRef] [PubMed] 
60. Levy, B.D.; Kohli, P.; Gotlinger, K.; Haworth, O.; Hong, S.; Kazani, S.; Israel, E.; Haley, K.J.; Serhan, C.N. Protectin D1 Is Generated in Asthma and Dampens Airway Inflammation and Hyperresponsiveness. J. Immunol. 2007, 178, 496-502. [CrossRef]

61. Levy, B.D.; De Sanctis, G.T.; Devchand, P.R.; Kim, E.; Ackerman, K.; Schmidt, B.A.; Szczeklik, W.; Drazen, J.M.; Serhan, C.N. Multi-Pronged Inhibition of Airway Hyper-Responsiveness and Inflammation by Lipoxin A4. Nat. Med. 2002, 8, 1018-1023. [CrossRef]

62. Kong, X.; Wu, S.H.; Zhang, L.; Chen, X.Q. Pilot Application of Lipoxin A4 Analog and Lipoxin A4 Receptor Agonist in Asthmatic Children with Acute Episodes. Exp. Ther. Med. 2017, 14, 2284-2290. [CrossRef]

63. Wu, S.H.; Chen, X.Q.; Liu, B.; Wu, H.J.; Dong, L. Efficacy and Safety of 15(R/S)-Methyl-Lipoxin A4 in Topical Treatment of Infantile Eczema. Br. J. Dermatol. 2013, 168, 172-178. [CrossRef]

64. Haruna, T.; Soga, M.; Morioka, Y.; Imura, K.; Furue, Y.; Yamamoto, M.; Hayakawa, J.; Deguchi, M.; Arimura, A.; Yasui, K. The Inhibitory Effect of S-777469, a Cannabinoid Type 2 Receptor Agonist, on Skin Inflammation in Mice. Pharmacology 2017, 99, 259-267. [CrossRef]

65. Abohalaka, R.; Bozkurt, T.E.; Nemutlu, E.; Onder, S.C.; Sahin-Erdemli, I. The Effects of Fatty Acid Amide Hydrolase and Monoacylglycerol Lipase Inhibitor Treatments on Lipopolysaccharide-Induced Airway Inflammation in Mice. Pulm. Pharmacol. Ther. 2020, 62, 101920. [CrossRef] [PubMed]

66. Larose, M.C.; Turcotte, C.; Chouinard, F.; Ferland, C.; Martin, C.; Provost, V.; Laviolette, M.; Flamand, N. Mechanisms of Human Eosinophil Migration Induced by the Combination of IL-5 and the Endocannabinoid 2-Arachidonoyl-Glycerol. J. Allergy Clin. Immunol. 2014, 133, 1480-1482.e3. [CrossRef]

67. Park, G.Y.; Lee, Y.G.; Berdyshev, E.; Nyenhuis, S.; Du, J.; Fu, P.; Gorshkova, I.A.; Li, Y.; Chung, S.; Karpurapu, M.; et al. Autotaxin Production of Lysophosphatidic Acid Mediates Allergic Asthmatic Inflammation. Am. J. Respir. Crit. Care Med. 2013, 188, 928-940. [CrossRef] [PubMed]

68. Jendzjowsky, N.G.; Roy, A.; Barioni, N.O.; Kelly, M.M.; Green, F.H.Y.; Wyatt, C.N.; Pye, R.L.; Tenorio-Lopes, L.; Wilson, R.J.A. Preventing Acute Asthmatic Symptoms by Targeting a Neuronal Mechanism Involving Carotid Body Lysophosphatidic Acid Receptors. Nat. Commun. 2018, 9, 1-15. [CrossRef] [PubMed]

69. Perkins, T.N.; Oczypok, E.A.; Dutz, R.E.; Donnell, M.L.; Myerburg, M.M.; Oury, T.D. The Receptor for Advanced Glycation End Products Is a Critical Mediator of Type 2 Cytokine Signaling in the Lungs. J. Allergy Clin. Immunol. 2019, 144, 796-808.e12. [CrossRef] [PubMed]

70. Bouchette, D.; Preuss, C. V Zileuton; StatPearls Publishing: Treasure Island, FL, USA, 2020.

71. Choi, J.; Azmat, C.E. Leukotriene Receptor Antagonists; StatPearls Publishing: Treasure Island, FL, USA, 2020.

72. Aritake, K.; Kado, Y.; Inoue, T.; Miyano, M.; Urade, Y. Structural and Functional Characterization of HQL-79, an Orally Selective Inhibitor of Human Hematopoietic Prostaglandin D Synthase. J. Biol. Chem. 2006, 281, 15277-15286. [CrossRef] [PubMed]

73. Aoyagi, H.; Kajiwara, D.; Tsunekuni, K.; Tanaka, K.; Miyoshi, K.; Hirasawa, N. Potential Synergistic Effects of Novel Hematopoietic Prostaglandin D Synthase Inhibitor TAS-205 and Different Types of Anti-Allergic Medicine on Nasal Obstruction in a Guinea Pig Model of Experimental Allergic Rhinitis. Eur. J. Pharmacol. 2020, 875, 173030. [CrossRef] [PubMed]

74. Brightling, C.E.; Gaga, M.; Inoue, H.; Li, J.; Maspero, J.; Wenzel, S.; Maitra, S.; Lawrence, D.; Brockhaus, F.; Lehmann, T.; et al. Effectiveness of Fevipiprant in Reducing Exacerbations in Patients with Severe Asthma (LUSTER-1 and LUSTER-2): Two Phase 3 Randomised Controlled Trials. Lancet Respir. Med. 2021, 9, 43-56. [CrossRef]

75. Okubo, K.; Hashiguchi, K.; Takeda, T.; Baba, K.; Kitagoh, H.; Miho, H.; Tomomatsu, H.; Yamaguchi, S.; Odani, M.; Yamamotoya, H. A Randomized Controlled Phase II Clinical Trial Comparing ONO-4053, a Novel DP1 Antagonist, with a Leukotriene Receptor Antagonist Pranlukast in Patients with Seasonal Allergic Rhinitis. Allergy Eur. J. Allergy Clin. Immunol. 2017, 72, 1565-1575. [CrossRef]

76. Sturm, E.M.; Schratl, P.; Schuligoi, R.; Konya, V.; Sturm, G.J.; Lippe, I.T.; Peskar, B.A.; Heinemann, A. Prostaglandin E2 Inhibits Eosinophil Trafficking through E-Prostanoid 2 Receptors. J. Immunol. 2008, 181, 7273-7283. [CrossRef]

77. Serra-Pages, M.; Torres, R.; Plaza, J.; Herrerias, A.; Costa-Farré, C.; Marco, A.; Jiménez, M.; Maurer, M.; Picado, C.; de Mora, F. Activation of the Prostaglandin E2 Receptor EP2 Prevents House Dust Mite-Induced Airway Hyperresponsiveness and Inflammation by Restraining Mast Cells' Activity. Clin. Exp. Allergy 2015, 45, 1590-1600. [CrossRef]

78. Idzko, M.; Hammad, H.; Van Nimwegen, M.; Kool, M.; Vos, N.; Hoogsteden, H.C.; Lambrecht, B.N. Inhaled Iloprost Suppresses the Cardinal Features of Asthma via Inhibition of Airway Dendritic Cell Function. J. Clin. Investig. 2007, 117, 464-472. [CrossRef]

79. Sturm, E.M.; Schuligoi, R.; Konya, V.; Sturm, G.J.; Heinemann, A. Inhibitory Effect of Prostaglandin I2 on Bone Marrow Kinetics of Eosinophils in the Guinea Pig. J. Leukoc. Biol. 2011, 90, 285-291. [CrossRef] [PubMed]

80. Miller, L.A.; Cossette, C.; Chourey, S.; Ye, Q.; Reddy, C.N.; Rokach, J.; Powell, W.S. Inhibition of Allergen-Induced Dermal Eosinophilia by an Oxoeicosanoid Receptor Antagonist in Non-Human Primates. Br. J. Pharmacol. 2020, 177, 360-371. [CrossRef] [PubMed]

81. Adler, D.H.; Cogan, J.D.; Phillips, J.A.; Schnetz-Boutaud, N.; Milne, G.L.; Iverson, T.; Stein, J.A.; Brenner, D.A.; Morrow, J.D.; Boutaud, O.; et al. Inherited Human CPLA2 $\alpha$ Deficiency Is Associated with Impaired Eicosanoid Biosynthesis, Small Intestinal Ulceration, and Platelet Dysfunction. J. Clin. Investig. 2008, 118, 2121-2131. [CrossRef] [PubMed]

82. Hallstrand, T.S.; Chi, E.Y.; Singer, A.G.; Gelb, M.H.; Henderson, W.R. Secreted Phospholipase A2 Group X Overexpression in Asthma and Bronchial Hyperresponsiveness. Am. J. Respir. Crit. Care Med. 2007, 176, 1072-1078. [CrossRef] 
83. Urasaki, T.; Ninomiya, H.; Takasaki, J.; Kawauchi, Y.; Nagasawa, T.; Masuho, Y. Cytosolic Phospholipase A2, Increased and Activated in the Eosinophils of Patients with Hypereosinophilic Syndrome in Vivo, Is Involved in the Augmented Release of Leukotriene C4. Inflamm. Res. 1999, 48, 36-40. [CrossRef]

84. Clark, J.D.; Williams, C.M.M. Utility of cytosolic phospholipase A2 $\alpha$ (cPLA2 $\alpha$ ) inhibitors in the treatment of asthma. In New Drugs and Targets for Asthma and COPD; S. Karger AG: Basel, Switzerland, 2010; Volume 39, pp. 207-212. ISBN 9783805595674.

85. Nikolaou, A.; Kokotou, M.G.; Vasilakaki, S.; Kokotos, G. Small-Molecule Inhibitors as Potential Therapeutics and as Tools to Understand the Role of Phospholipases A2. Biochim. Biophys. Acta Mol. Cell Biol. Lipids 2019, 1864, 941-956. [CrossRef] [PubMed]

86. Hewson, C.A.; Patel, S.; Calzetta, L.; Campwala, H.; Havard, S.; Luscombe, E.; Clarke, P.A.; Peachell, P.T.; Matera, M.G.; Cazzola, M.; et al. Preclinical Evaluation of an Inhibitor of Cytosolic Phospholipase A $2 \alpha$ for the Treatment of Asthma. J. Pharmacol. Exp. Ther. 2012, 340, 656-665. [CrossRef]

87. Karasawa, K.; Harada, A.; Satoh, N.; Inoue, K.; Setaka, M. Plasma Platelet Activating Factor-Acetylhydrolase (PAF-AH). Prog. Lipid Res. 2003, 42, 93-114. [CrossRef]

88. Snyder, F. Platelet-Activating Factor: The Biosynthetic and Catabolic Enzymes. Biochem. J. 1995, 305, 689-705. [CrossRef]

89. Gill, P.; Jindal, N.L.; Jagdis, A.; Vadas, P. Platelets in the Immune Response: Revisiting Platelet-Activating Factor in Anaphylaxis. J. Allergy Clin. Immunol. 2015, 135, 1424-1432. [CrossRef]

90. Dyer, K.D.; Percopo, C.M.; Xie, Z.; Yang, Z.; Kim, J.D.; Davoine, F.; Lacy, P.; Druey, K.M.; Moqbel, R.; Rosenberg, H.F. Mouse and Human Eosinophils Degranulate in Response to Platelet-Activating Factor (PAF) and LysoPAF via a PAF-Receptor-Independent Mechanism: Evidence for a Novel Receptor. J. Immunol. 2010, 184, 6327-6334. [CrossRef]

91. Kroegel, C.; Matthys, H. Platelet-Activating Factor-Induced Human Eosinophil Activation. Generation and Release of CycloOxygenase Metabolites in Human Blood Eosinophils from Asthmatics. Immunology 1993, 78, 279-285. [PubMed]

92. Bankers-Fulbright, J.L.; Kephart, G.M.; Bartemes, K.R.; Kita, H.; O'Grady, S.M. Platelet-Activating Factor Stimulates Cytoplasmic Alkalinization and Granule Acidification in Human Eosinophils. J. Cell Sci. 2004, 117, 5749-5757. [CrossRef]

93. Wardlaw, A.J.; Moqbel, R.; Cromwell, O.; Kay, A.B. Platelet-Activating Factor. A Potent Chemotactic and Chemokinetic Factor for Human Eosinophils. J. Clin. Investig. 1986, 78, 1701-1706. [CrossRef] [PubMed]

94. Mullol, J. Positioning of Antihistamines in the Allergic Rhinitis and Its Impact on Asthma (ARIA) Guidelines. Clin. Exp. Allergy Rev. 2012, 12, 17-26. [CrossRef]

95. Mullol, J.; Izquierdo, I.; Okubo, K.; Canonica, G.W.; Bousquet, J.; Valero, A. Clinically Relevant Effect of Rupatadine 20 Mg and $10 \mathrm{Mg}$ in Seasonal Allergic Rhinitis: A Pooled Responder Analysis. Clin. Transl. Allergy 2019, 9, 1-10. [CrossRef]

96. Santamaría, E.; Izquierdo, I.; Valle, M.; Vermeulen, J.; Potter, P. Rupatadine Oral Solution for 2-5-Year-Old Children with Allergic Rhinitis: A Safety, Open-Label, Prospective Study. J. Asthma Allergy 2018, 11, 225-231. [CrossRef] [PubMed]

97. Potter, P.; Maspero, J.F.; Vermeulen, J.; Barkai, L.; Németh, I.; Baillieau, R.A.; Garde, J.M.; Giralt, J.; Doménech, A.; Izquierdo, I.; et al. Rupatadine Oral Solution in Children with Persistent Allergic Rhinitis: A Randomized, Double-Blind, Placebo-Controlled Study. Pediatr. Allergy Immunol. 2013, 24, 144-150. [CrossRef] [PubMed]

98. Nieto, A.; Nieto, M.; Mazón, Á. The Clinical Evidence of Second-Generation H1-Antihistamines in the Treatment of Allergic Rhinitis and Urticaria in Children over 2 Years with a Special Focus on Rupatadine. Expert Opin. Pharmacother. 2020, 22, 511-519. [CrossRef] [PubMed]

99. Roberts, G.; Xatzipsalti, M.; Borrego, L.M.; Custovic, A.; Halken, S.; Hellings, P.W.; Papadopoulos, N.G.; Rotiroti, G.; Scadding, G.; Timmermans, F.; et al. Paediatric Rhinitis: Position Paper of the European Academy of Allergy and Clinical Immunology. Allergy 2013, 68, 1102-1116. [CrossRef] [PubMed]

100. Church, M.K.; Maurer, M.; Simons, F.E.R.; Bindslev-Jensen, C.; Van Cauwenberge, P.; Bousquet, J.; Holgate, S.T.; Zuberbier, T. Risk of First-Generation H1-Antihistamines: A GA2LEN Position Paper. Allergy Eur. J. Allergy Clin. Immunol. 2010, 65, 459-466. [CrossRef]

101. Knuplez, E.; Curcic, S.; Theiler, A.; Bärnthaler, T.; Trakaki, A.; Trieb, M.; Holzer, M.; Heinemann, A.; Zimmermann, R.; Sturm, E.M.; et al. Lysophosphatidylcholines Inhibit Human Eosinophil Activation and Suppress Eosinophil Migration in Vivo. Biochim. Biophys. Acta Mol. Cell Biol. Lipids 2020, 1865, 158686. [CrossRef]

102. Hwang, S.M.; Kim, H.J.; Kim, S.M.; Jung, Y.; Park, S.W.; Chung, I.Y. Lysophosphatidylserine Receptor P2Y10: A G Protein-Coupled Receptor That Mediates Eosinophil Degranulation. Clin. Exp. Allergy 2018, 48, 990-999. [CrossRef] [PubMed]

103. Frei, R.B.; Luschnig, P.; Parzmair, G.P.; Peinhaupt, M.; Schranz, S.; Fauland, A.; Wheelock, C.E.; Heinemann, A.; Sturm, E.M. Cannabinoid Receptor 2 Augments Eosinophil Responsiveness and Aggravates Allergen-Induced Pulmonary Inflammation in Mice. Allergy Eur. J. Allergy Clin. Immunol. 2016, 71, 944-956. [CrossRef]

104. Czech, W.; Barbisch, M.; Tenscher, K.; Schöpf, E.; Schröder, J.M.; Norgauer, J. Chemotactic 5-Oxo-Eicosatetraenoic Acids Induce Oxygen Radical Production, $\mathrm{Ca}^{2+}$-Mobilization, and Actin Reorganization in Human Eosinophils via a Pertussis Toxin-Sensitive G-Protein. J. Investig. Dermatol. 1997, 108, 108-112. [CrossRef]

105. Schwenk, U.; Morita, E.; Engel, R.; Schröder, J.M. Identification of 5-Oxo-15-Hydroxy-6,8,11,13-Eicosatetraenoic Acid as a Novel and Potent Human Eosinophil Chemotactic Eicosanoid. J. Biol. Chem. 1992, 267, 12482-12488. [CrossRef]

106. Sturm, G.J.; Schuligoi, R.; Sturm, E.M.; Royer, J.F.; Lang-Loidolt, D.; Stammberger, H.; Amann, R.; Peskar, B.A.; Heinemann, A. 5-Oxo-6,8,11,14-Eicosatetraenoic Acid Is a Potent Chemoattractant for Human Basophils. J. Allergy Clin. Immunol. 2005, 116, 1014-1019. [CrossRef] 
107. Muro, S.; Hamid, Q.; Olivenstein, R.; Taha, R.; Rokach, J.; Powell, W.S. 5-Oxo-6,8,11,14-Eicosatetraenoic Acid Induces the Infiltration of Granulocytes into Human Skin. J. Allergy Clin. Immunol. 2003, 112, 768-774. [CrossRef]

108. Lin, L.; Chen, Z.; Tang, X.; Dai, F.; Wei, J.; Sun, G. 5-Oxo-ETE from Nasal Epithelial Cells Upregulates Eosinophil Cation Protein by Eosinophils in Nasal Polyps in Vitro. Int. Arch. Allergy Immunol. 2018, 177, 107-115. [CrossRef]

109. Fregonese, L.; Silvestri, M.; Sabatini, F.; Rossi, G.A. Cysteinyl Leukotrienes Induce Human Eosinophil Locomotion and Adhesion Molecule Expression via a CysLT 1 Receptor-Mediated Mechanism. Clin. Exp. Allergy 2002, 32, 745-750. [CrossRef] [PubMed]

110. Saito, K.; Nagata, M.; Kikuchi, I.; Sakamoto, Y. Leukotriene D4 and Eosinophil Transendothelial Migration, Superoxide Generation, and Degranulation via B2 Integrin. Ann. Allergy Asthma Immunol. 2004, 93, 594-600. [CrossRef]

111. Neves, J.S.; Radke, A.L.; Weller, P.F. Cysteinyl Leukotrienes Acting via Granule Membrane-Expressed Receptors Elicit Secretion from within Cell-Free Human Eosinophil Granules. J. Allergy Clin. Immunol. 2010, 125, 477-482. [CrossRef]

112. Tager, A.M.; Dufour, J.H.; Goodarzi, K.; Bercury, S.D.; Von Andrian, U.H.; Luster, A.D. BLTR Mediates Leukotriene B4-Induced Chemotaxis and Adhesion and Plays a Dominant Role in Eosinophil Accumulation in a Murine Model of Peritonitis. J. Exp. Med. 2000, 192, 439-446. [CrossRef] [PubMed]

113. Idzko, M.; Laut, M.; Panther, E.; Sorichter, S.; Durk, T.; Fluhr, J.W.; Herouy, Y.; Mockenhaupt, M.; Myrtek, D.; Elsner, P.; et al. Lysophosphatidic Acid Induces Chemotaxis, Oxygen Radical Production, CD11b Up-Regulation, Ca ${ }^{2+}$ Mobilization, and Actin Reorganization in Human Eosinophils via Pertussis Toxin-Sensitive G Proteins. J. Immunol. 2004, 172, 4480-4485. [CrossRef]

114. Hashimoto, T.; Yamashita, M.; Ohata, H.; Momose, K. Lysophosphatidic Acid Enhances in Vivo Infiltration and Activation of Guinea Pig Eosinophils and Neutrophils via a Rho/Rho-Associated Protein Kinase-Mediated Pathway. J. Pharmacol. Sci. 2003, 91, 8-14. [CrossRef]

115. Zhu, X.; Learoyd, J.; Butt, S.; Zhu, L.; Usatyuk, P.V.; Natarajan, V.; Munoz, N.M.; Leff, A.R. Regulation of Eosinophil Adhesion by Lysophosphatidylcholine via a Non-Store-Operated Ca ${ }^{2+}$ Channel. Am. J. Respir. Cell Mol. Biol. 2007, 36, 585-593. [CrossRef]

116. Nishiyama, O.; Kume, H.; Kondo, M.; Ito, Y.; Ito, M.; Yamaki, K. Role of Lysophosphatidylcholine in Eosinophil Infiltration and Resistance in Airways. Clin. Exp. Pharmacol. Physiol. 2004, 31, 179-184. [CrossRef]

117. Kim, H.J.; Sim, M.S.; Lee, D.H.; Kim, C.; Choi, Y.; Park, H.; Chung, I.Y. Lysophosphatidylserine Induces Eosinophil Extracellular Trap Formation and Degranulation: Implications in Severe Asthma. Allergy 2020, 75, 3159-3170. [CrossRef]

118. Gervais, F.G.; Cruz, R.P.G.; Chateauneuf, A.; Gale, S.; Sawyer, N.; Nantel, F.; Metters, K.M.; O’Neill, G.P. Selective Modulation of Chemokinesis, Degranulation, and Apoptosis in Eosinophils through the PGD2 Receptors CRTH2 and DP. J. Allergy Clin. Immunol. 2001, 108, 982-988. [CrossRef] [PubMed]

119. Hirai, H.; Tanaka, K.; Yoshie, O.; Ogawa, K.; Kenmotsu, K.; Takamori, Y.; Ichimasa, M.; Sugamura, K.; Nakamura, M.; Takano, S.; et al. Prostaglandin D2 Selectively Induces Chemotaxis in T Helper Type 2 Cells, Eosinophils, and Basophils via SevenTransmembrane Receptor CRTH2. J. Exp. Med. 2001, 193, 255-261. [CrossRef]

120. Schratl, P.; Sturm, E.M.; Royer, J.F.; Sturm, G.J.; Lippe, I.T.; Peskar, B.A.; Heinemann, A. Hierarchy of Eosinophil Chemoattractants: Role of P38 Mitogen-Activated Protein Kinase. Eur. J. Immunol. 2006, 36, 2401-2409. [CrossRef]

121. Heinemann, A.; Schuligoi, R.; Sabroe, I.; Hartnell, A.; Peskar, B.A. $\Delta 12-$ Prostaglandin J2, a Plasma Metabolite of Prostaglandin D2, Causes Eosinophil Mobilization from the Bone Marrow and Primes Eosinophils for Chemotaxis. J. Immunol. 2003, 170, 4752-4758. [CrossRef] [PubMed]

122. Peinhaupt, M.; Roula, D.; Theiler, A.; Sedej, M.; Schicho, R.; Marsche, G.; Sturm, E.M.; Sabroe, I.; Rothenberg, M.E.; Heinemann, A. DP1 Receptor Signaling Prevents the Onset of Intrinsic Apoptosis in Eosinophils and Functions as a Transcriptional Modulator. J. Leukoc. Biol. 2018, 104, 159-171. [CrossRef]

123. Mesquita-Santos, F.P.; Bakker-Abreu, I.; Luna-Gomes, T.; Bozza, P.T.; Diaz, B.L.; Bandeira-Melo, C. Co-Operative Signalling through DP1 and DP2 Prostanoid Receptors Is Required to Enhance Leukotriene C4 Synthesis Induced by Prostaglandin D2 in Eosinophils. Br. J. Pharmacol. 2011, 162, 1674-1685. [CrossRef]

124. Luschnig-Schratl, P.; Sturm, E.M.; Konya, V.; Philipose, S.; Marsche, G.; Fröhlich, E.; Samberger, C.; Lang-Loidolt, D.; Gattenlöhner, S.; Lippe, I.T.; et al. EP4 Receptor Stimulation Down-Regulates Human Eosinophil Function. Cell. Mol. Life Sci. 2011, 68, 3573-3587. [CrossRef] [PubMed]

125. Peacock, C.D.; Misso, N.L.A.; Watkins, D.N.; Thompson, P.J. PGE2 and Dibutyryl Cyclic Adenosine Monophosphate Prolong Eosinophil Survival In Vitro. J. Allergy Clin. Immunol. 1999, 104, 153-162. [CrossRef]

126. Daffern, P.J.; Jagels, M.A.; Saad, J.J.; Fischer, W.; Hugli, T.E. Upper Airway Epithelial Cells Support Eosinophil Survival In Vitro through Production of GM-CSF and Prostaglandin E2: Regulation by Glucocorticoids and TNF- $\alpha$. Allergy Asthma Proc. 1999, 20, 243-253. [CrossRef] [PubMed]

127. Gauvreau, G.M.; Watson, R.M.; O’Byrne, P.M. Protective Effects of Inhaled PGE2 on Allergen-Induced Airway Responses and Airway Inflammation. Am. J. Respir. Crit. Care Med. 1999, 159, 31-36. [CrossRef] [PubMed]

128. Konya, V.; Sturm, E.M.; Schratl, P.; Beubler, E.; Marsche, G.; Schuligoi, R.; Lippe, I.T.; Peskar, B.A.; Heinemann, A.; Austria, G. Endothelium-Derived Prostaglandin I 2 Controls the Migration of Eosinophils. J. Allergy Clin. Immunol. 2010, 125, 1105-1113. [CrossRef]

129. Miyata, J.; Fukunaga, K.; Iwamoto, R.; Isobe, Y.; Niimi, K.; Takamiya, R.; Takihara, T.; Tomomatsu, K.; Suzuki, Y.; Oguma, T.; et al. Dysregulated Synthesis of Protectin D1 in Eosinophils from Patients with Severe Asthma. J. Allergy Clin. Immunol. 2013, 131, 353-360.e2. [CrossRef] 
130. Rabini, R.A.; Galassi, R.; Fumelli, P.; Dousset, N.; Solera, M.L.; Valdiguie, P.; Curatola, G.; Ferretti, G.; Taus, M.; Mazzanti, L. Reduced Na+-K+-ATPase Activity and Plasma Lysophosphatidylcholine Concentrations in Diabetic Patients. Diabetes 1994, 43, 915-919. [CrossRef]

131. Mcmahon, H.T.; Boucrot, E. Membrane Curvature at a Glance. J. Cell Sci. 2015, 128, 1065-1070. [CrossRef] [PubMed]

132. Lawrence, A.J.; Moores, G.R.; Steele, J. A Conductimetric Study of Erythrocyte Lysis by Lysolecithin and Linoleic Acid. Eur. J. Biochem. 1974, 48, 277-286. [CrossRef]

133. Yoder, M.; Zhuge, Y.; Yuan, Y.; Holian, O.; Kuo, S.; van Breemen, R.; Thomas, L.L.; Lum, H. Bioactive Lysophosphatidylcholine 16:0 and 18:0 Are Elevated in Lungs of Asthmatic Subjects. Allergy. Asthma Immunol. Res. 2014, 6, 61. [CrossRef]

134. Ried, J.S.; Baurecht, H.; Stückler, F.; Krumsiek, J.; Gieger, C.; Heinrich, J.; Kabesch, M.; Prehn, C.; Peters, A.; Rodriguez, E.; et al Integrative Genetic and Metabolite Profiling Analysis Suggests Altered Phosphatidylcholine Metabolism in Asthma. Allergy Eur. J. Allergy Clin. Immunol. 2013, 68, 629-636. [CrossRef]

135. Knuplez, E.; Marsche, G. An Updated Review of Pro-and Anti-Inflammatory Properties of Plasma Lysophosphatidylcholines in the Vascular System. Int. J. Mol. Sci. 2020, 21, 4501. [CrossRef]

136. Marathe, G.K.; Silva, A.R.; de Castro Faria Neto, H.C.; Tjoelker, L.W.; Prescott, S.M.; Zimmerman, G.A.; McIntyre, T.M. Lysophosphatidylcholine and Lyso-PAF Display PAF-like Activity Derived from Contaminating Phospholipids. J. Lipid Res. 2001, 42, 1430-1437. [CrossRef]

137. Bansal, P.; Gaur, S.N.; Arora, N. Lysophosphatidylcholine Plays Critical Role in Allergic Airway Disease Manifestation. Sci. Rep. 2016, 6, 1-10. [CrossRef] [PubMed]

138. Aoki, J.; Taira, A.; Takanezawa, Y.; Kishi, Y.; Hama, K.; Kishimoto, T.; Mizuno, K.; Saku, K.; Taguchi, R.; Arai, H. Serum Lysophosphatidic Acid Is Produced through Diverse Phospholipase Pathways. J. Biol. Chem. 2002, 277, 48737-48744. [CrossRef] [PubMed]

139. Diamanti, K.; Cavalli, M.; Pan, G.; Pereira, M.J.; Kumar, C.; Skrtic, S.; Grabherr, M.; Risérus, U.; Eriksson, J.W.; Komorowski, J.; et al. Intra- and Inter-Individual Metabolic Profiling Highlights Carnitine and Lysophosphatidylcholine Pathways as Key Molecular Defects in Type 2 Diabetes. Sci. Rep. 2019, 9, 9653. [CrossRef] [PubMed]

140. Kwatia, M.A.; Doyle, C.B.; Cho, W.; Enhorning, G.; Ackerman, S.J. Combined Activities of Secretory Phospholipases and Eosinophil Lysophospholipases Induce Pulmonary Surfactant Dysfunction by Phospholipid Hydrolysis. J. Allergy Clin. Immunol. 2007, 119, 838-847. [CrossRef]

141. Weller, P.F.; Wang, H.; Melo, R.C.N. The Charcot-Leyden Crystal Protein Revisited-A Lysopalmitoylphospholipase and More. J. Leukoc. Biol. 2020, 108, 105-112. [CrossRef]

142. Weller, P.F.; Goetzl, E.J.; Austen, K.F. Identification of Human Eosinophil Lysophospholipase as the Constituent of Charcot-Leyden Crystals. Proc. Natl. Acad. Sci. USA 1980, 77, 7440-7443. [CrossRef]

143. Nyenhuis, S.M.; Alumkal, P.; Du, J.; Maybruck, B.T.; Vinicky, M.; Ackerman, S.J. Charcot-Leyden Crystal Protein/Galectin-10 Is a Surrogate Biomarker of Eosinophilic Airway Inflammation in Asthma. Biomark. Med. 2019, 13, 715-724. [CrossRef]

144. Persson, E.K.; Verstraete, K.; Heyndrickx, I.; Gevaert, E.; Aegerter, H.; Percier, J.M.; Deswarte, K.; Verschueren, K.H.G.; Dansercoer, A.; Gras, D.; et al. Protein Crystallization Promotes Type 2 Immunity and Is Reversible by Antibody Treatment. Science 2019, 364, eaaw4295. [CrossRef]

145. Cunningham, T.J.; Yao, L.; Lucena, A. Product Inhibition of Secreted Phospholipase A2 May Explain Lysophosphatidylcholines' Unexpected Therapeutic Properties. J. Inflamm. 2008, 5, 17. [CrossRef]

146. Hanna, V.S.; Hafez, E.A.A. Synopsis of Arachidonic Acid Metabolism: A Review. J. Adv. Res. 2018, 11, 23-32. [CrossRef] [PubMed]

147. Elagizi, A.; Lavie, C.J.; O’keefe, E.; Marshall, K.; O’keefe, J.H.; Milani, R.V. An Update on Omega-3 Polyunsaturated Fatty Acids and Cardiovascular Health. Nutrients 2021, 13, 204. [CrossRef]

148. Suzumura, A.; Terao, R.; Kaneko, H. Protective Effects and Molecular Signaling of N-3 Fatty Acids on Oxidative Stress and Inflammation in Retinal Diseases. Antioxidants 2020, 9, 920. [CrossRef]

149. Hutchinson, A.N.; Tingö, L.; Brummer, R.J. The Potential Effects of Probiotics and w-3 Fatty Acids on Chronic Low-Grade Inflammation. Nutrients 2020, 12, 2402. [CrossRef] [PubMed]

150. Balić, A.; Vlašić, D.; Žužul, K.; Marinović, B.; Mokos, Z.B. Omega-3 versus Omega-6 Polyunsaturated Fatty Acids in the Prevention and Treatment of Inflammatory Skin Diseases. Int. J. Mol. Sci. 2020, 21, 741. [CrossRef]

151. Kwiatkowska, B.; Maślińska, M. The Place of Omega-3 and Omega-6 Acids in Supplementary Treatment of Inflammatory Joint Diseases. Reumatologia 2020, 58, 34-41. [CrossRef] [PubMed]

152. Calder, P.C. Mechanisms of Action of (n-3) Fatty Acids. J. Nutr. 2012, 142, 592S-599S. [CrossRef]

153. Dong, L.; Zou, H.; Yuan, C.; Hong, Y.H.; Kuklev, D.V.; Smith, W.L. Different Fatty Acids Compete with Arachidonic Acid for Binding to the Allosteric or Catalytic Subunits of Cyclooxygenases to Regulate Prostanoid Synthesis. J. Biol. Chem. 2016, 291, 4069-4078. [CrossRef] [PubMed]

154. Samuchiwal, S.K.; Boyce, J.A. Role of Lipid Mediators and Control of Lymphocyte Responses in Type 2 Immunopathology. J. Allergy Clin. Immunol. 2018, 141, 1182-1190. [CrossRef]

155. Harizi, H.; Corcuff, J.B.; Gualde, N. Arachidonic-Acid-Derived Eicosanoids: Roles in Biology and Immunopathology. Trends Mol. Med. 2008, 14, 461-469. [CrossRef]

156. Dennis, E.A.; Norris, P.C. Eicosanoid Storm in Infection and Inflammation. Nat. Rev. Immunol. 2015, 15, 511-523. [CrossRef] 
157. Arita, M. Eosinophil Polyunsaturated Fatty Acid Metabolism and Its Potential Control of Inflammation and Allergy. Allergol. Int. 2016, 65, S2-S5. [CrossRef]

158. Serhan, C.N.; Dalli, J.; Colas, R.A.; Winkler, J.W.; Chiang, N. Protectins and Maresins: New pro-Resolving Families of Mediators in Acute Inflammation and Resolution Bioactive Metabolome. Biochim. Biophys. Acta Mol. Cell Biol. Lipids 2015, 1851, $397-413$. [CrossRef] [PubMed]

159. Krishnamoorthy, N.; Abdulnour, R.E.E.; Walker, K.H.; Engstrom, B.D.; Levy, B.D. Specialized Proresolving Mediators in Innate and Adaptive Immune Responses in Airway Diseases. Physiol. Rev. 2018, 98, 1335-1370. [CrossRef] [PubMed]

160. Isobe, Y.; Arita, M.; Matsueda, S.; Iwamoto, R.; Fujihara, T.; Nakanishi, H.; Taguchi, R.; Masuda, K.; Sasaki, K.; Urabe, D.; et al. Identification and Structure Determination of Novel Anti-Inflammatory Mediator Resolvin E3, 17,18-Dihydroxyeicosapentaenoic Acid. J. Biol. Chem. 2012, 287, 10525-10534. [CrossRef] [PubMed]

161. Çelik, G.E.; Erkekol, F.O.; Misirligil, Z.; Melli, M. Lipoxin A4 Levels in Asthma: Relation with Disease Severity and Aspirin Sensitivity. Clin. Exp. Allergy 2007, 37, 1494-1501. [PubMed]

162. Sanak, M.; Levy, B.D.; Clish, C.B.; Chiang, N.; Gronert, K.; Mastalerz, L.; Serhan, C.N.; Szczeklik, A. Aspirin-Tolerant Asthmatics Generate More Lipoxins than Aspirin- Intolerant Asthmatics. Eur. Respir. J. 2000, 16, 44-49. [CrossRef] [PubMed]

163. Wu, S.H.; Yin, P.L.; Zhang, Y.M.; Tao, H.X. Reversed Changes of Lipoxin A4 and Leukotrienes in Children with Asthma in Different Severity Degree. Pediatr. Pulmonol. 2010, 45, 333-340. [CrossRef]

164. Planagumà, A.; Kazani, S.; Marigowda, G.; Haworth, O.; Mariani, T.J.; Israel, E.; Bleecker, E.R.; Curran-Everett, D.; Erzurum, S.C.; Calhoun, W.J.; et al. Airway Lipoxin A4 Generation and Lipoxin A4 Receptor Expression Are Decreased in Severe Asthma. Am. J. Respir. Crit. Care Med. 2008, 178, 574-582. [CrossRef]

165. Miyata, J.; Fukunaga, K.; Kawashima, Y.; Ohara, O.; Arita, M. Cysteinyl Leukotriene Metabolism of Human Eosinophils in Allergic Disease. Allergol. Int. 2020, 69, 28-34. [CrossRef] [PubMed]

166. Yokomizo, T.; Nakamura, M.; Shimizu, T. Leukotriene Receptors as Potential Therapeutic Targets. J. Clin. Investig. 2018, 128, 2691-2701. [CrossRef]

167. Thompson-Souza, G.A.; Gropillo, I.; Neves, J.S. Cysteinyl Leukotrienes in Eosinophil Biology: Functional Roles and Therapeutic Perspectives in Eosinophilic Disorders. Front. Med. 2017, 4, 106. [CrossRef]

168. Steinke, J.W.; Negri, J.; Payne, S.C.; Borish, L. Biological Effects of Leukotriene E4 on Eosinophils. Prostaglandins Leukot. Essent. Fat. Acids 2014, 91, 105-110. [CrossRef]

169. Bandeira-Melo, C.; Weller, P.F. Eosinophils and Cysteinyl Leukotrienes. Prostaglandins Leukot. Essent. Fat. Acids 2003, 69, 135-143. [CrossRef]

170. Chen, K.; Yu, Z.; Yang, J.; Li, H. Expression of Cysteinyl Leukotriene Receptor GPR17 in Eosinophilic and Non-Eosinophilic Chronic Rhinosinusitis with Nasal Polyps. Asian Pacific J. Allergy Immunol. 2018, 36, 93-100.

171. Liu, M.; Yokomizo, T. The Role of Leukotrienes in Allergic Diseases. Allergol. Int. 2015, 64, 17-26. [CrossRef]

172. Kamohara, M.; Takasaki, J.; Matsumoto, M.; Saito, T.; Ohishi, T.; Ishii, H.; Furuichi, K. Molecular Cloning and Characterization of Another Leukotriene B4 Receptor. J. Biol. Chem. 2000, 275, 27000-27004. [CrossRef]

173. Serhan, C.N.; Prescott, S.M. The Scent of a Phagocyte: Advances on Leukotriene B4 Receptors. J. Exp. Med. 2000, 192, F5-F8. [CrossRef]

174. Yokomizo, T.; Izumi, T.; Chang, K.; Takuwa, Y.; Shimizu, T. A G-Protein-Coupled Receptor for Leukotriene B4 That Mediates Chemotaxis. Nature 1997, 387, 620-624. [CrossRef] [PubMed]

175. Pal, K.; Feng, X.; Steinke, J.W.; Burdick, M.D.; Shim, Y.M.; Sung, S.S.; Gerald Teague, W.; Borish, L. Leukotriene A4 Hydrolase Activation and Leukotriene B4 Production by Eosinophils in Severe Asthma. Am. J. Respir. Cell Mol. Biol. 2019, 60, 413-419. [CrossRef]

176. Jo-Watanabe, A.; Okuno, T.; Yokomizo, T. The Role of Leukotrienes as Potential Therapeutic Targets in Allergic Disorders. Int. J. Mol. Sci. 2019, 20, 3580. [CrossRef] [PubMed]

177. Thomas Scow, D.; Luttermoser, G.K.; Scott Dickerson, K. Leukotriene Inhibitors in the Treatment of Allergy and Asthma. Am. Fam. Physician 2007, 75, 65-70.

178. Ujino, M.; Sugimoto, N.; Koizumi, Y.; Ro, S.; Kojima, Y.; Asae, K.H.; Yamashita, N.; Ohta, K.; Nagase, H. Leukotriene Receptor Antagonist Attenuated Airway Inflammation and Hyperresponsiveness in a Double-Stranded RNA-Induced Asthma Exacerbation Model. Allergol. Int. 2017, 66, S21-S26. [CrossRef]

179. Turner, C.R.; Breslow, R.; Conklyn, M.J.; Andresen, C.J.; Patterson, D.K.; Lopez-Anaya, A.; Owens, B.; Lee, P.; Watson, J.W.; Showell, H.J. In Vitro and in Vivo Effects of Leukotriene B4 Antagonism in a Primate Model of Asthma. J. Clin. Investig. 1996, 97, 381-387. [CrossRef]

180. Evans, D.J.; Barnes, P.J.; Spaethe, S.M.; Van Alstyne, E.L.; Mitchell, M.I.; O'Connor, B.J. Effect of a Leukotriene B4 Receptor Antagonist, LY293111, on Allergen Induced Responses in Asthma. Thorax 1996, 51, 1178-1184. [CrossRef]

181. Asanuma, F.; Kuwabara, K.; Arimura, A.; Furue, Y.; Fleisch, J.H.; Hori, Y. Effects of Leukotriene B4 Receptor Antagonist, LY293111Na, on Antigen-Induced Bronchial Hyperresponsiveness and Leukocyte Infiltration in Sensitized Guinea Pigs. Inflamm. Res. 2001, 50, 136-141. [CrossRef] [PubMed]

182. Gelfand, E.W. Importance of the Leukotriene B4-BLT1 and LTB4-BLT2 Pathways in Asthma. Semin. Immunol. 2017, 33, 44-51. [CrossRef] 
183. Kandhare, A.D.; Liu, Z.; Mukherjee, A.A.; Bodhankar, S.L. Therapeutic Potential of Morin in Ovalbumin-Induced Allergic Asthma Via Modulation of SUMF2/IL-13 and BLT2/NF-KB Signaling Pathway. Curr. Mol. Pharmacol. 2019, 12, 122-138. [CrossRef]

184. Liu, M.; Shen, J.; Yuan, H.; Chen, F.; Song, H.; Qin, H.; Li, Y.; Xu, J.; Ye, Q.; Li, S.; et al. Leukotriene B4 Receptor 2 Regulates the Proliferation, Migration, and Barrier Integrity of Bronchial Epithelial Cells. J. Cell. Physiol. 2018, 233, 6117-6124. [CrossRef] [PubMed]

185. Matsunaga, Y.; Fukuyama, S.; Okuno, T.; Sasaki, F.; Matsunobu, T.; Asai, Y.; Matsumoto, K.; Saeki, K.; Oike, M.; Sadamura, Y.; et al. Leukotriene $B_{4}$ Receptor BLT2 Negatively Regulates Allergic Airway Eosinophilia. FASEB J. 2013, 27, 3306-3314. [CrossRef] [PubMed]

186. Feltenmark, S.; Gautam, N.; Brunnström, Å.; Griffiths, W.; Backman, L.; Edenius, C.; Lindbom, L.; Björkholm, M.; Claesson, H.E. Eoxins Are Proinflammatory Arachidonic Acid Metabolites Produced via the 15-Lipoxygenase-1 Pathway in Human Eosinophils and Mast Cells. Proc. Natl. Acad. Sci. USA 2008, 105, 680-685. [CrossRef]

187. Claesson, H.E. On the Biosynthesis and Biological Role of Eoxins and 15-Lipoxygenase-1 in Airway Inflammation and Hodgkin Lymphoma. Prostaglandins Other Lipid Mediat. 2009, 89, 120-125. [CrossRef] [PubMed]

188. Brunnström, Å.; Tryselius, Y.; Feltenmark, S.; Andersson, E.; Leksell, H.; James, A.; Mannervik, B.; Dahlén, B.; Claesson, H.E. On the Biosynthesis of 15-HETE and Eoxin C4 by Human Airway Epithelial Cells. Prostaglandins Other Lipid Mediat. 2015, 121, 83-90. [CrossRef] [PubMed]

189. Chu, H.W.; Balzar, S.; Westcott, J.Y.; Trudeau, J.B.; Sun, Y.; Conrad, D.J.; Wenzel, S.E. Expression and Activation of 15-Lipoxygenase Pathway in Severe Asthma: Relationship to Eosinophilic Phenotype and Collagen Deposition. Clin. Exp. Allergy 2002, 32, 15581565. [CrossRef]

190. Laprise, C.; Sladek, R.; Ponton, A.; Bernier, M.C.; Hudson, T.J.; Laviolette, M. Functional Classes of Bronchial Mucosa Genes That Are Differentially Expressed in Asthma. BMC Genom. 2004, 5, 21. [CrossRef]

191. Shannon, V.R.; Chanez, P.; Bousquet, J.; Holtzman, M.J. Histochemical Evidence for Induction of Arachidonate 15-Lipoxygenase in Airway Disease. Am. Rev. Respir. Dis. 1993, 147, 1024-1028. [CrossRef]

192. Sachs-Olsen, C.; Sanak, M.; Lang, A.M.; Gielicz, A.; Mowinckel, P.; Lødrup Carlsen, K.C.; Carlsen, K.H.; Szczeklik, A. Eoxins: A New Inflammatory Pathway in Childhood Asthma. J. Allergy Clin. Immunol. 2010, 126, 859-867.e9. [CrossRef]

193. Ono, E.; Mita, H.; Taniguchi, M.; Higashi, N.; Hasegawa, M.; Miyazaki, E.; Kumamoto, T.; Akiyama, K. Concentration of 14,15-Leukotriene C4 (Eoxin C4) in Bronchoalveolar Lavage Fluid. Clin. Exp. Allergy 2009, 39, 1348-1352. [CrossRef]

194. Lee, K.; Lee, S.H.; Kim, T.H. The Biology of Prostaglandins and Their Role as a Target for Allergic Airway Disease Therapy. Int. J. Mol. Sci. 2020, 21, 1851. [CrossRef]

195. Urade, Y.; Eguchi, N. Lipocalin-Type and Hematopoietic Prostaglandin D Synthases as a Novel Example of Functional Convergence. Prostaglandins Other Lipid Mediat. 2002, 68-69, 375-382. [CrossRef]

196. Rittchen, S.; Heinemann, A. Therapeutic Potential of Hematopoietic Prostaglandin D2 Synthase in Allergic Inflammation. Cells 2019, 8, 619. [CrossRef] [PubMed]

197. Peinhaupt, M.; Sturm, E.M.; Heinemann, A. Prostaglandins and Their Receptors in Eosinophil Function and as Therapeutic Targets. Front. Med. 2017, 4, 104. [CrossRef] [PubMed]

198. Park, J.Y.; Pillinger, M.H.; Abramson, S.B. Prostaglandin E2 Synthesis and Secretion: The Role of PGE2 Synthases. Clin. Immunol. 2006, 119, 229-240. [CrossRef] [PubMed]

199. Insuela, D.B.R.; Ferrero, M.R.; de Coutinho, D.S.; Martins, M.A.; Carvalho, V.F. Could Arachidonic Acid-Derived Pro-Resolving Mediators Be a New Therapeutic Strategy for Asthma Therapy? Front. Immunol. 2020, 11, 1. [CrossRef]

200. Luna-Gomes, T.; Magalhães, K.G.; Mesquita-Santos, F.P.; Bakker-Abreu, I.; Samico, R.F.; Molinaro, R.; Calheiros, A.S.; Diaz, B.L.; Bozza, P.T.; Weller, P.F.; et al. Eosinophils as a Novel Cell Source of Prostaglandin D2: Autocrine Role in Allergic Inflammation. J. Immunol. 2011, 187, 6518-6526. [CrossRef]

201. Feng, X.; Ramsden, M.K.; Negri, J.; Baker, M.G.; Payne, S.C.; Borish, L.; Steinke, J.W. Eosinophil Production of Prostaglandin D2 in Patients with Aspirin-Exacerbated Respiratory Disease. J. Allergy Clin. Immunol. 2016, 138, 1089-1097.e3. [CrossRef] [PubMed]

202. Okano, M.; Fujiwara, T.; Sugata, Y.; Gotoh, D.; Masaoka, Y.; Sogo, M.; Tanimoto, W.; Yamamoto, M.; Matsumoto, R.; Eguchi, N.; et al. Presence and Characterization of Prostaglandin D2-Related Molecules in Nasal Mucosa of Patients with Allergic Rhinitis. Am. J. Rhinol. 2006, 20, 342-348. [CrossRef]

203. Suzuki, N.; Ko-Mitamura, E.P.; Inui, T.; Terada, T.; Dejima, K.; Nagata, N.; Urade, Y.; Kawata, R. Steroids Inhibit Eosinophil Accumulation and Downregulate Hematopoietic Chemotaxic Prostaglandin D2 Receptor in Aspirin-Exacerbated Respiratory Disease. Ear Nose Throat J. 2020, 20, 342-348. [CrossRef]

204. Sedej, M.; Schröder, R.; Bell, K.; Platzer, W.; Vukoja, A.; Kostenis, E.; Heinemann, A.; Waldhoer, M. D-Type Prostanoid Receptor Enhances the Signaling of Chemoattractant Receptor-Homologous Molecule Expressed on TH2 Cells. J. Allergy Clin. Immunol. 2012, 129, 492-500.e9. [CrossRef]

205. Profita, M.; Sala, A.; Bonanno, A.; Riccobono, L.; Siena, L.; Melis, M.R.; Di Giorgi, R.; Mirabella, F.; Gjomarkaj, M.; Bonsignore, G.; et al. Increased Prostaglandin E2 Concentrations and Cyclooxygenase-2 Expression in Asthmatic Subjects with Sputum Eosinophilia. J. Allergy Clin. Immunol. 2003, 112, 709-716. [CrossRef]

206. Sastre, B.; Fernández-Nieto, M.; Mollá, R.; López, E.; Lahoz, C.; Sastre, J.; del Pozo, V.; Quirce, S. Increased Prostaglandin E 2 Levels in the Airway of Patients with Eosinophilic Bronchitis. Allergy 2007, 63, 58-66. 
207. Bateman, E.D.; O'Brien, C.; Rugman, P.; Luke, S.; Ivanov, S.; Uddin, M. Efficacy and Safety of the CRTh2 Antagonist AZD1981 as Add-on Therapy to Inhaled Corticosteroids and Long-Acting B2-Agonists in Patients with Atopic Asthma. Drug Des. Devel. Ther. 2018, 12, 1093-1106. [CrossRef] [PubMed]

208. Tsuge, K.; Inazumi, T.; Shimamoto, A.; Sugimoto, Y. Molecular Mechanisms Underlying Prostaglandin E 2-Exacerbated Inflammation and Immune Diseases. Int. Immunol. 2019, 31, 597-606. [CrossRef] [PubMed]

209. Mizuno, R.; Kawada, K.; Sakai, Y. Prostaglandin E2/EP Signaling in the Tumor Microenvironment of Colorectal Cancer. Int. J. Mol. Sci. 2019, 20, 6254. [CrossRef] [PubMed]

210. Woolbright, B.L.; Pilbeam, C.C.; Taylor, J.A. Prostaglandin E2 as a Therapeutic Target in Bladder Cancer: From Basic Science to Clinical Trials. Prostaglandins Other Lipid Mediat. 2020, 148, 106409. [CrossRef] [PubMed]

211. Johnson, A.M.; Kleczko, E.K.; Nemenoff, R.A. Eicosanoids in Cancer: New Roles in Immunoregulation. Front. Pharmacol. 2020, 11, 595498. [CrossRef] [PubMed]

212. Aggarwal, S.; Moodley, Y.P.; Thompson, P.J.; Misso, N.L. Prostaglandin E2 and Cysteinyl Leukotriene Concentrations in Sputum: Association with Asthma Severity and Eosinophilic Inflammation. Clin. Exp. Allergy 2010, 40, 85-93.

213. Ricke-Hoch, M.; Stelling, E.; Lasswitz, L.; Kasten, M.; Zapatero-Belinchón, F.J.; Brogden, G.; Gerold, G.; Battmer, K.; Pietschmann, T.; Montiel, V.; et al. SARS-CoV-2-Induced Impaired Immune Response by Prostaglandin E2 Is Accelerated by Age, Male Sex and Air Pollution. Res. Sq. 2020. [CrossRef]

214. Dorris, S.L.; Peebles, R.S. PGI 2 as a Regulator of Inflammatory Diseases. Mediat. Inflamm. 2012, 2012, 1-9. [CrossRef]

215. Durchschein, F.; Eherer, A.; Grill, M.; Sturm, E.M.; Pommer, V.; Langner, C.; Högenauer, C.; Schicho, R. Involvement of EP2 and EP4 Receptors in Eosinophilic Esophagitis: A Pilot Study. Dig. Dis. Sci. 2019, 64, 2806-2814. [CrossRef]

216. Konya, V.; Philipose, S.; Bálint, Z.; Olschewski, A.; Marsche, G.; Sturm, E.M.; Schicho, R.; Peskar, B.A.; Schuligoi, R.; Heinemann, A. Interaction of Eosinophils with Endothelial Cells Is Modulated by Prostaglandin EP4 Receptors. Eur. J. Immunol. 2011, 41, 2379-2389. [CrossRef]

217. Plaza, J.; Torres, R.; Urbano, A.; Picado, C.; de Mora, F. In Vitro and In Vivo Validation of EP2-Receptor Agonism to Selectively Achieve Inhibition of Mast Cell Activity. Allergy. Asthma Immunol. Res. 2020, 12, 712. [CrossRef]

218. Nakanishi, M.; Rosenberg, D.W. Multifaceted Roles of PGE2 in Inflammation and Cancer. Semin. Immunopathol. 2013, 35, $123-137$. [CrossRef] [PubMed]

219. Babaev, V.R.; Chew, J.D.; Ding, L.; Davis, S.; Breyer, M.D.; Breyer, R.M.; Oates, J.A.; Fazio, S.; Linton, M.F. Macrophage EP4 Deficiency Increases Apoptosis and Suppresses Early Atherosclerosis. Cell Metab. 2008, 8, 492-501. [CrossRef]

220. Coulombe, F.; Jaworska, J.; Verway, M.; Tzelepis, F.; Massoud, A.; Gillard, J.; Wong, G.; Kobinger, G.; Xing, Z.; Couture, C.; et al Targeted Prostaglandin E2 Inhibition Enhances Antiviral Immunity through Induction of Type I Interferon and Apoptosis in Macrophages. Immunity 2014, 40, 554-568. [CrossRef] [PubMed]

221. Bergqvist, F.; Morgenstern, R.; Jakobsson, P.J. A Review on MPGES-1 Inhibitors: From Preclinical Studies to Clinical Applications. Prostaglandins Other Lipid Mediat. 2020, 147, 106383. [CrossRef]

222. Sheibanie, A.F.; Khayrullina, T.; Safadi, F.F.; Ganea, D. Prostaglandin E2 Exacerbates Collagen-Induced Arthritis in Mice through the Inflammatory Interleukin-23/Interleukin-17 Axis. Arthritis Rheum. 2007, 56, 2608-2619. [CrossRef] [PubMed]

223. Schölkens, B.A.; Bartmann, W.; Beck, G.; Lerch, U.; Konz, E.; Weithmann, U. Vasodilation and Inhibition of Platelet Aggregation by Prostacyclins with Modified $\omega$-Side Chain. Prostaglandines Med. 1979, 3, 7-22. [CrossRef]

224. Kuang, H.; Li, Q.; Yi, Q.; Lu, T. The Efficacy and Safety of Aerosolized Iloprost in Pulmonary Arterial Hypertension: A Systematic Review and Meta-Analysis. Am. J. Cardiovasc. Drugs 2019, 19, 393-401. [CrossRef]

225. Johansson, P.I.; Bestle, M.; Søe-Jensen, P.; Kristiansen, K.T.; Stensballe, J.; Clausen, N.E.; Perner, A. The Effect of Prostacyclin (Iloprost) Infusion at a Dose of $1 \mathrm{Ng} / \mathrm{Kg} / \mathrm{Min}$ for 72 Hours Compared to Placebo in Mechanically Ventilated Patients with COVID-19: A Structured Summary of a Study Protocol for a Randomized Controlled Trial. Trials 2020, 21, 746. [CrossRef] [PubMed]

226. Monneret, G.; Gravel, S.; Diamond, M.; Rokach, J.; Powell, W.S. Prostaglandin D2 Is a Potent Chemoattractant for Human Eosinophils That Acts via a Novel DP Receptor. Blood 2001, 98, 1942-1948. [CrossRef]

227. Powell, W.S.; Chung, D.; Gravel, S. 5-Oxo-6,8,11,14-Eicosatetraenoic Acid Is a Potent Stimulator of Human Eosinophil Migration. J. Immunol. 1995, 154, 4123 LP-4132 LP.

228. Simons, B.; Ferrini, M.E.; Carvalho, S.; Bassett, D.J.P.; Jaffar, Z.; Roberts, K. PGI 2 Controls Pulmonary NK Cells That Prevent Airway Sensitization to House Dust Mite Allergen. J. Immunol. 2017, 198, 461-471. [CrossRef]

229. Goetzl, E.J.; Goldman, D.W.; Naccache, P.H.; Sha'afi, R.I.; Pickett, W.C. Mediation of Leukocyte Components of Inflammatory Reactions by Lipoxygenase Products of Arachidonic Acid. Adv. Prostaglandin. Thromboxane. Leukot. Res. 1982, 9, $273-282$. [PubMed]

230. Powell, W.S.; Rokach, J.; Biophys, B.; Author, A. Biosynthesis, Biological Effects, and Receptors of Hydroxyeicosatetraenoic Acids (HETEs) and Oxoeicosatetraenoic Acids (Oxo-ETEs) Derived from Arachidonic Acid HHS Public Access Author Manuscript. Biochim. Biophys. Acta 2015, 1851, 340-355. [CrossRef]

231. Kowal, K.; Gielicz, A.; Sanak, M. The Effect of Allergen-Induced Bronchoconstriction on Concentration of 5-Oxo-ETE in Exhaled Breath Condensate of House Dust Mite-Allergic Patients. Clin. Exp. Allergy 2017, 47, 1253-1262. [CrossRef] 
232. Jones, C.E.; Holden, S.; Tenaillon, L.; Bhatia, U.; Seuwen, K.; Tranter, P.; Turner, J.; Kettle, R.; Bouhelal, R.; Charlton, S.; et al. Expression and Characterization of a 5-Oxo-6 E,8 Z,11 Z,14 Z-Eicosatetraenoic Acid Receptor Highly Expressed on Human Eosinophils and Neutrophils. Mol. Pharmacol. 2003, 63, 471-477. [CrossRef] [PubMed]

233. Hosoi, T.; Koguchi, Y.; Sugikawa, E.; Chikada, A.; Ogawa, K.; Tsuda, N.; Suto, N.; Tsunoda, S.; Taniguchi, T.; Ohnuki, T. Identification of a Novel Human Eicosanoid Receptor Coupled to Gi/O. J. Biol. Chem. 2002, 277, 31459-31465. [CrossRef] [PubMed]

234. Powell, W.S.; Rokach, J. The Eosinophil Chemoattractant 5-Oxo-ETE and the OXE Receptor. Prog. Lipid Res. 2013, 52, 651-665. [CrossRef]

235. Urasaki, T.; Takasaki, J.; Nagasawa, T.; Ninomiya, H. Pivotal Role of 5-Lipoxygenase in the Activation of Human Eosinophils: Platelet-Activating Factor and Interleukin-5 Induce CD69 on Eosinophils through the 5-Lipoxygenase Pathway. J. Leukoc. Biol. 2001, 69, 105-112. [PubMed]

236. O’Flaherty, J.T.; Kuroki, M.; Nixon, A.B.; Wijkander, J.; Yee, E.; Lee, S.L.; Smitherman, P.K.; Wykle, R.L.; Daniel, L.W. 5-OxoEicosatetraenoate Is a Broadly Active, Eosinophil-Selective Stimulus for Human Granulocytes. J. Immunol. 1996, 157, 336-342.

237. Langlois, A.; Chouinard, F.; Flamand, N.; Ferland, C.; Rola-Pleszczynski, M.; Laviolette, M. Crucial Implication of Protein Kinase C (PKC)-, PKC-, ERK-1/2, and P38 MAPK in Migration of Human Asthmatic Eosinophils. J. Leukoc. Biol. 2009, 85, 656-663. [CrossRef] [PubMed]

238. Guilbert, M.; Ferland, C.; Bossé, M.; Flamand, N.; Lavigne, S.; Laviolette, M. 5-Oxo-6,8,11,14-Eicosatetraenoic Acid Induces Important Eosinophil Transmigration through Basement Membrane Components: Comparison of Normal and Asthmatic Eosinophils. Am. J. Respir. Cell Mol. Biol. 1999, 21, 97-104. [CrossRef]

239. Patel, K.; Davison, J.; Pittman, Q.; Sharkey, K. Cannabinoid CB2 Receptors in Health and Disease. Curr. Med. Chem. 2010, 17, 1394-1410. [CrossRef]

240. Zoppi, S.; Madrigal, J.L.; Caso, J.R.; García-Gutiérrez, M.S.; Manzanares, J.; Leza, J.C.; García-Bueno, B. Regulatory Role of the Cannabinoid CB2 Receptor in Stress-Induced Neuroinflammation in Mice. Br. J. Pharmacol. 2014, 171, 2814-2826. [CrossRef] [PubMed]

241. Powell, W.S.; Rokach, J. Targeting the OXE Receptor as a Potential Novel Therapy for Asthma. Biochem. Pharmacol. 2020, 179, 113930. [CrossRef]

242. Kadamur, G.; Ross, E.M. Mammalian Phospholipase C. Annu. Rev. Physiol. 2013, 75, 127-154. [CrossRef] [PubMed]

243. Berridge, M.J. The Inositol Trisphosphate/Calcium Signaling Pathway in Health and Disease. Physiol. Rev. 2016, 96, 1261-1296. [CrossRef]

244. Kroegel, C.; Chilvers, E.R.; Giembycz, M.A.; Challiss, R.A.J.; Barnes, P.J. Platelet-Activating Factor Stimulates a Rapid Accumulation of Inositol $(1,4,5)$ Trisphosphate in Guinea Pig Eosinophils: Relationship to Calcium Mobilization and Degranulation. J. Allergy Clin. Immunol. 1991, 88, 114-124. [CrossRef]

245. Sano, A.; Zhu, X.; Sano, H.; Muñoz, N.M.; Boetticher, E.; Leff, A.R. Regulation of Eosinophil Function by PhosphatidylinositolSpecific PLC and Cytosolic PLA 2. Am. J. Physiol. Cell. Mol. Physiol. 2001, 281, L844-L851. [CrossRef]

246. Nakao, M.; Sugaya, M.; Suga, H.; Kawaguchi, M.; Morimura, S.; Kai, H.; Ohmatsu, H.; Fujita, H.; Asano, Y.; Tada, Y.; et al. Serum Autotaxin Levels Correlate with Pruritus in Patients with Atopic Dermatitis. J. Investig. Dermatol. 2014, 134, 1745-1747. [CrossRef] [PubMed]

247. Maher, T.M.; Kreuter, M.; Lederer, D.J.; Brown, K.K.; Wuyts, W.; Verbruggen, N.; Stutvoet, S.; Fieuw, A.; Ford, P.; Abi-Saab, W.; et al. Rationale, Design and Objectives of Two Phase III, Randomised, Placebo-Controlled Studies of GLPG1690, a Novel Autotaxin Inhibitor, in Idiopathic Pulmonary Fibrosis (ISABELA 1 and 2). BMJ Open Respir. Res. 2019, 6, e000422. [CrossRef] [PubMed]

248. Reisenberg, M.; Singh, P.K.; Williams, G.; Doherty, P. The Diacylglycerol Lipases: Structure, Regulation and Roles in and beyond Endocannabinoid Signalling. Philos. Trans. R. Soc. B Biol. Sci. 2012, 367, 3264-3275. [CrossRef] [PubMed]

249. Turcotte, C.; Archambault, A.S.; Dumais, É.; Martin, C.; Blanchet, M.R.; Bissonnette, E.; Ohashi, N.; Yamamoto, K.; Itoh, T.; Laviolette, M.; et al. Endocannabinoid Hydrolysis Inhibition Unmasks That Unsaturated Fatty Acids Induce a Robust Biosynthesis of 2-Arachidonoyl-Glycerol and Its Congeners in Human Myeloid Leukocytes. FASEB J. 2020, 34, 4253-4265. [CrossRef]

250. Angelina, A.; Pérez-Diego, M.; López-Abente, J.; Palomares, O. The Role of Cannabinoids in Allergic Diseases: Collegium Internationale Allergologicum (CIA) Update 2020. Int. Arch. Allergy Immunol. 2020, 181, 565-584. [CrossRef]

251. Kondo, M.; Tezuka, T.; Ogawa, H.; Koyama, K.; Bando, H.; Azuma, M.; Nishioka, Y. Lysophosphatidic Acid Regulates the Differentiation of Th2 Cells and Its Antagonist Suppresses Allergic Airway Inflammation. Int. Arch. Allergy Immunol. 2021, 182, 1-13. [CrossRef]

252. Kim, S.J.; Moon, H.G.; Park, G.Y. The Roles of Autotaxin/Lysophosphatidic Acid in Immune Regulation and Asthma. Biochim. Biophys. Acta Mol. Cell Biol. Lipids 2020, 1865, 158641. [CrossRef]

253. Nieto-Posadas, A.; Picazo-Juárez, G.; Llorente, I.; Jara-Oseguera, A.; Morales-Lázaro, S.; Escalante-Alcalde, D.; Islas, L.D.; Rosenbaum, T. Lysophosphatidic Acid Directly Activates TRPV1 through a C-Terminal Binding Site. Nat. Chem. Biol. 2012, 8, 78-85. [CrossRef] [PubMed]

254. Oka, S.; Ikeda, S.; Kishimoto, S.; Gokoh, M.; Yanagimoto, S.; Waku, K.; Sugiura, T. 2-Arachidonoylglycerol, an Endogenous Cannabinoid Receptor Ligand, Induces the Migration of EoL-1 Human Eosinophilic Leukemia Cells and Human Peripheral Blood Eosinophils. J. Leukoc. Biol. 2004, 76, 1002-1009. [CrossRef] [PubMed] 
255. Kishimoto, S.; Oka, S.; Gokoh, M.; Sugiura, T. Chemotaxis of Human Peripheral Blood Eosinophils to 2-Arachidonoylglycerol: Comparison with Other Eosinophil Chemoattractants. In Proceedings of the International Archives of Allergy and Immunology. Int. Arch. Allergy Immunol. 2006, 140, 3-7. [CrossRef]

256. Rai, V.; Touré, F.; Chitayat, S.; Pei, R.; Song, F.; Li, Q.; Zhang, J.; Rosario, R.; Ramasamy, R.; Chazin, W.J.; et al. Lysophosphatidic Acid Targets Vascular and Oncogenic Pathways via RAGE Signaling. J. Exp. Med. 2012, 209, 2339-2350. [CrossRef] [PubMed]

257. Zhang, C.; Baker, D.L.; Yasuda, S.; Makarova, N.; Balazs, L.; Johnson, L.R.; Marathe, G.K.; McIntyre, T.M.; Xu, Y.; Prestwich, G.D.; et al. Lysophosphatidic Acid Induces Neointima Formation Through PPAR $\gamma$ Activation. J. Exp. Med. 2004, 199, 763-774. [CrossRef] [PubMed]

258. Oka, S.; Wakui, J.; Ikeda, S.; Yanagimoto, S.; Kishimoto, S.; Gokoh, M.; Nasui, M.; Sugiura, T. Involvement of the Cannabinoid CB2 Receptor and Its Endogenous Ligand 2-Arachidonoylglycerol in Oxazolone-Induced Contact Dermatitis in Mice. J. Immunol. 2006, 177, 8796-8805. [CrossRef] [PubMed]

259. Maresz, K.; Carrier, E.J.; Ponomarev, E.D.; Hillard, C.J.; Dittel, B.N. Modulation of the Cannabinoid CB2 Receptor in Microglial Cells in Response to Inflammatory Stimuli. J. Neurochem. 2005, 95, 437-445. [CrossRef]

260. Steffens, S.; Veillard, N.R.; Arnaud, C.; Pelli, G.; Burger, F.; Staub, C.; Zimmer, A.; Frossard, J.L.; Mach, F. Low Dose Oral Cannabinoid Therapy Reduces Progression of Atherosclerosis in Mice. Nature 2005, 434, 782-786. [CrossRef]

261. Ackerman, S.J.; Park, G.Y.; Christman, J.W.; Nyenhuis, S.; Berdyshev, E.; Natarajan, V. Polyunsaturated Lysophosphatidic Acid as a Potential Asthma Biomarker. Biomark. Med. 2016, 10, 123-135. [CrossRef]

262. Shimizu, Y.; Murao, K.; Tanaka, T.; Kubo, Y.; Tokumura, A. Increased Lysophospholipase D Activity of Autotaxin in Sera of Patients with Atopic Dermatitis. J. Dermatol. Sci. 2014, 74, 162-165. [CrossRef] [PubMed]

263. Park, S.J.; Jun, Y.J.; Lee, K.J.; Hwang, S.M.; Kim, T.H.; Lee, S.H.; Lee, S.H. Chronic Rhinosinusitis with Nasal Polyps and without Nasal Polyps Is Associated with Increased Expression of Lysophosphatidic Acid-Related Molecules. Am. J. Rhinol. Allergy 2014, 28, 199-207. [CrossRef]

264. Knowlden, S.; Georas, S.N. The Autotaxin-LPA Axis Emerges as a Novel Regulator of Lymphocyte Homing and Inflammation. J. Immunol. 2014, 192, 851-857. [CrossRef]

265. Zhao, Y.; Tong, J.; He, D.; Pendyala, S.; Evgeny, B.; Chun, J.; Sperling, A.I.; Natarajan, V. Role of Lysophosphatidic Acid Receptor LPA 2 in the Development of Allergic Airway Inflammation in a Murine Model of Asthma. Respir. Res. 2009, 10, 1-12. [CrossRef]

266. Oczypok, E.A.; Perkins, T.N.; Oury, T.D. All the "RAGE" in Lung Disease: The Receptor for Advanced Glycation Endproducts (RAGE) Is a Major Mediator of Pulmonary Inflammatory Responses. Paediatr. Respir. Rev. 2017, 23, 40-49. [CrossRef]

267. Perkins, T.N.; Donnell, M.L.; Oury, T.D. The Axis of the Receptor for Advanced Glycation Endproducts in Asthma and Allergic Airway Disease. Allergy 2020, 14600. [CrossRef]

268. Milutinovic, P.S.; Alcorn, J.F.; Englert, J.M.; Crum, L.T.; Oury, T.D. The Receptor for Advanced Glycation End Products Is a Central Mediator of Asthma Pathogenesis. Am. J. Pathol. 2012, 181, 1215-1225. [CrossRef] [PubMed]

269. Ullah, M.A.; Loh, Z.; Gan, W.J.; Zhang, V.; Yang, H.; Li, J.H.; Yamamoto, Y.; Schmidt, A.M.; Armour, C.L.; Hughes, J.M.; et al Receptor for Advanced Glycation End Products and Its Ligand High-Mobility Group Box-1 Mediate Allergic Airway Sensitization and Airway Inflammation. J. Allergy Clin. Immunol. 2014, 134, 440-450.e3. [CrossRef] [PubMed]

270. Brandt, E.B.; Lewkowich, I.P. RAGE-Induced Asthma: A Role for the Receptor for Advanced Glycation End-Products in Promoting Allergic Airway Disease. J. Allergy Clin. Immunol. 2019, 144, 651-653. [CrossRef]

271. Curran, C.S.; Bertics, P.J. Human Eosinophils Express RAGE, Produce RAGE Ligands, Exhibit PKC-Delta Phosphorylation and Enhanced Viability in Response to the RAGE Ligand, S100B. Int. Immunol. 2011, 23, 713-728. [CrossRef]

272. Dyer, K.D.; Rosenberg, H.F. Physiologic Concentrations of HMGB1 Have No Impact on Cytokine-Mediated Eosinophil Survival or Chemotaxis in Response to Eotaxin-2 (CCL24). PLoS ONE 2015, 10, e0118887. [CrossRef]

273. Wood, L.G.; Gibson, P.G.; Garg, M.L. Biomarkers of Lipid Peroxidation, Airway Inflammation and Asthma. Eur. Respir. J. 2003, 21, 177-186. [CrossRef] [PubMed]

274. Levine, S.J. Bronchial Epithelial Cell-Cytokine Interactions in Airway Inflammation. J. Investig. Med. Off. Publ. Am. Fed. Clin. Res. 1995, 43, 241-249.

275. Doelman, C.J.A.; Bast, A. Oxygen Radicals in Lung Pathology. Free Radic. Biol. Med. 1990, 9, 381-400. [CrossRef]

276. Dweik, R.A.; Comhair, S.A.A.; Gaston, B.; Thunnissen, F.B.J.M.; Farver, C.; Thomassen, M.J.; Kavuru, M.; Hammel, J.; Abu-Soud, H.M.; Erzurum, S.C. NO Chemical Events in the Human Airway during the Immediate and Late Antigen-Induced Asthmatic Response. Proc. Natl. Acad. Sci. USA 2001, 98, 2622-2627. [CrossRef]

277. MacPherson, J.C.; Comhair, S.A.A.; Erzurum, S.C.; Klein, D.F.; Lipscomb, M.F.; Kavuru, M.S.; Samoszuk, M.K.; Hazen, S.L. Eosinophils Are a Major Source of Nitric Oxide-Derived Oxidants in Severe Asthma: Characterization of Pathways Available to Eosinophils for Generating Reactive Nitrogen Species. J. Immunol. 2001, 166, 5763-5772. [CrossRef] [PubMed]

278. Comhair, S.A.A.; Erzurum, S.C. Redox Control of Asthma: Molecular Mechanisms and Therapeutic Opportunities. Antioxid. Redox Signal. 2010, 12, 93-124. [CrossRef] [PubMed]

279. Hulsmann, A.R.; Raatgeep, H.R.; Den Hollander, J.C.; Stijnen, T.; Saxena, P.R.; Kerrebijn, K.F.; De Jongste, J.C. Oxidative Epithelial Damage Produces Hyperresponsiveness of Human Peripheral Airways. Am. J. Respir. Crit. Care Med. 1994, 149, 519-525. [CrossRef]

280. Qu, J.; Li, Y.; Zhong, W.; Gao, P.; Hu, C. Recent Developments in the Role of Reactive Oxygen Species in Allergic Asthma. J. Thorac. Dis. 2017, 9, E32-E43. [CrossRef] 
281. Petreccia, D.C.; Nauseef, W.M.; Clark, R.A. Respiratory Burst of Normal Human Eosinophils. J. Leukoc. Biol. 1987, 41, 283-288. [CrossRef] [PubMed]

282. Wang, Z.; DiDonato, J.A.; Buffa, J.; Comhair, S.A.; Aronica, M.A.; Dweik, R.A.; Lee, N.A.; Lee, J.J.; Thomassen, M.J.; Kavuru, M.; et al. Eosinophil Peroxidase Catalyzed Protein Carbamylation Participates in Asthma. J. Biol. Chem. 2016, $291,22118-22135$. [CrossRef]

283. Mitra, S.N.; Slungaard, A.; Hazen, S.L. Redox Report Communications in Free Radical Research Role of Eosinophil Peroxidase in the Origins of Protein Oxidation in Asthma. Redox Rep. 2013. [CrossRef]

284. Sedgwick, J.B.; Geiger, K.M.; Busse, W.W. Superoxide Generation by Hypodense Eosinophils from Patients with Asthma. Am. Rev. Respir. Dis. 1990, 142, 120-125. [CrossRef]

285. Lavinskiene, S.; Malakauskas, K.; Jeroch, J.; Hoppenot, D.; Sakalauskas, R. Functional Activity of Peripheral Blood Eosinophils in Allergen-Induced Late-Phase Airway Inflammation in Asthma Patients. J. Inflamm. 2015, 12, 25. [CrossRef]

286. Dworski, R. Oxidant Stress in Asthma. Thorax 2000, 55, 51S-53S. [CrossRef]

287. Silveira, J.S.; Antunes, G.L.; Kaiber, D.B.; da Costa, M.S.; Marques, E.P.; Ferreira, F.S.; Gassen, R.B.; Breda, R.V.; Wyse, A.T.S.; Pitrez, P.; et al. Reactive Oxygen Species Are Involved in Eosinophil Extracellular Traps Release and in Airway Inflammation in Asthma. J. Cell. Physiol. 2019, 234, 23633-23646. [CrossRef] [PubMed]

288. Repetto, M.; Semprine, J.; Boveris, A. Lipid Peroxidation: Chemical Mechanism, Biological Implications and Analytical Determination. In Lipid Peroxidation; InTech: Londond, UK, 2012.

289. Bultel-Poncé, V.; Durand, T.; Guy, A.; Oger, C.; Galano, J.-M. Non Enzymatic Metabolites of Polyunsaturated Fatty Acids: Friend or Foe. OCL 2016, 23, D118. [CrossRef]

290. Leung, K.S.; Galano, J.M.; Durand, T.; Lee, J.C.Y. Current Development in Non-Enzymatic Lipid Peroxidation Products, Isoprostanoids and Isofuranoids, in Novel Biological Samples. Free Radic. Res. 2015, 49, 816-826. [CrossRef]

291. Vigor, C.; Bertrand-Michel, J.; Pinot, E.; Oger, C.; Vercauteren, J.; Le Faouder, P.; Galano, J.M.; Lee, J.C.Y.; Durand, T. NonEnzymatic Lipid Oxidation Products in Biological Systems: ASSESSMENT of the Metabolites from Polyunsaturated Fatty Acids. J. Chromatogr. B Anal. Technol. Biomed. Life Sci. 2014, 964, 65-78. [CrossRef] [PubMed]

292. Dworski, R.; Murray, J.J.; Roberts, L.J.; Oates, J.A.; Morrow, J.D.; Fisher, L.; Sheller, J.R. Allergen-Induced Synthesis of F2Isoprostanes in Atopic Asthmatics: Evidence for Oxidant Stress. Am. J. Respir. Crit. Care Med. 1999, 160, 1947-1951. [CrossRef] [PubMed]

293. Chan, T.K.; Loh, X.Y.; Peh, H.Y.; Tan, W.N.F.; Tan, W.S.D.; Li, N.; Tay, I.J.J.; Wong, W.S.F.; Engelward, B.P. House Dust Mite-Induced Asthma Causes Oxidative Damage and DNA Double-Strand Breaks in the Lungs. J. Allergy Clin. Immunol. 2016, 138, 84-96.e1. [CrossRef] [PubMed]

294. Montuschi, P.; Corradi, M.; Ciabattoni, G.; Nightingale, J.; Kharitonov, S.A.; Barnes, P.J. Increased 8-Isoprostane, a Marker of Oxidative Stress, in Exhaled Condensate of Asthma Patients. Am. J. Respir. Crit. Care Med. 1999, 160, 216-220. [CrossRef]

295. Montuschi, P.; Barnes, P.J. Isoprostanes and Asthma. Drug Discov. Today Ther. Strateg. 2006, 3, 287-292. [CrossRef]

296. Shahid, S.K.; Kharitonov, S.A.; Wilson, N.M.; Bush, A.; Barnes, P.J. Exhaled 8-Isoprostane in Childhood Asthma. Respir. Res. 2005, 6, 79. [CrossRef]

297. Xie, J.; Zhang, Q.; Zhong, N.; Lai, K. BAL Fluid 8-Isoprostane Concentrations in Eosinophilic Bronchitis and Asthma. J. Asthma 2009, 46, 712-715. [CrossRef]

298. Groot, L.E.S.; Sabogal Piñeros, Y.S.; Bal, S.M.; Pol, M.A.; Hamann, J.; Sterk, P.J.; Kulik, W.; Lutter, R. Do Eosinophils Contribute to Oxidative Stress in Mild Asthma? Clin. Exp. Allergy 2019, 49, 929-931. [CrossRef]

299. M Leung, D.Y.; Ledford, D.K.; Moreno-Macias, H.; Romieu, I.; Mexico City, S. Clinical Reviews in Allergy and Immunology Effects of Antioxidant Supplements and Nutrients on Patients with Asthma and Allergies. J. Allergy Clin. Immunol. 2014, 133, 1237-1281.

300. Patel, B.D.; Welch, A.A.; Bingham, S.A.; Luben, R.N.; Day, N.E.; Khaw, K.T.; Lomas, D.A.; Wareham, N.J. Dietary Antioxidants and Asthma in Adults. Thorax 2006, 61, 388-393. [CrossRef]

301. Zhu, L.-Y.; Ni, Z.-H.; Luo, X.-M.; Wang, X.-B. Advance of Antioxidants in Asthma Treatment. World J. Respirol. $2017,7,17$. [CrossRef]

302. Burton, G.W.; Joyce, A.; Ingold, K.U. Is Vitamin E the Only Lipid-Soluble, Chain-Breaking Antioxidant in Human Blood Plasma and Erythrocyte Membranes? Arch. Biochem. Biophys. 1983, 221, 281-290. [CrossRef]

303. Smit, H.A.; Grievink, L.; Tabak, C. Dietary Influences on Chronic Obstructive Lung Disease and Asthma: A Review of the Epidemiological Evidence. In Nutrition Society; CAB International: Oxfordshire, UK, 1999; Volume 58, pp. 309-319.

304. Dow, L.; Tracey, M.; Villar, A.; Coggon, D.; Margetts, B.M.; Campbell, M.J.; Holgate, S.T. Does Dietary Intake of Vitamins C and E Influence Lung Function in Older People? Am. J. Respir. Crit. Care Med. 1996, 154, 1401-1404. [CrossRef] [PubMed]

305. Berdnikovs, S.; Abdala-Valencia, H.; McCary, C.; Somand, M.; Cole, R.; Garcia, A.; Bryce, P.; Cook-Mills, J.M. Isoforms of Vitamin E Have Opposing Immunoregulatory Functions during Inflammation by Regulating Leukocyte Recruitment. J. Immunol. 2009, 182, 4395-4405. [CrossRef] [PubMed] 